doc. dr. sc. Ana Ježovita

Ekonomski fakultet, Sveučilište u Zagrebu, Zagreb, Republika Hrvatska ajezovita@efzg.hr

\title{
ISTRAŽIVANJE RAZLIKA U UČINKOVITOSTI I FINANCIJSKOM STANJU PRORAČUNSKIH KORISNIKA U REPUBLICI HRVATSKOJ
}

Primljen: 15. srpnja 2019.

Prihvaćen: 16. studenog 2019.

Prethodno priopćenje

\section{Sažetak}

Jedinice središnje države, regionalne i lokalne samouprave svojim harmoniziranim aktivnostima trebaju težiti djelotvornom $i$ učinkovitom djelovanju usmjereno stvaranju nacionalnog bogatstva i povećanju prosječnog životnog standarda.Za razliku od profitno orijentiranih sustava, temeljni cilj djelovanja proračunskih korisnika je namjenska, djelotvorna $i$ učinkovita raspodjela proračunskih sredstava. Ciljevi djelovanja proračunskih korisnika trebaju biti usmjereni svrhovitosti, održivosti i trajnosti sustava. Važnu ulogu u oblikovanju načina upravljanja u javnoj upravi ima OECD koji svojim načelima korporativnog upravljanja u javnom sektoru nastoji dati smjernice upravljanja koje će voditi ostvarivanju ciljeva javne uprave u cjelini. Prema OECD-u, stupovi suvremenog upravljanja proračunom uključuju uvažavanje načela transparentnog $i$ odgovornog pristupa planiranju i ostvarivanju ciljeva te integriteta. U skladu s navedenim proizlazi problem istraživanja i pitanje koliko su jedinice središnje države u Republici Hrvatskoj učinkovite u upravljanju proračunskom sredstvima i koliko su financijski stabilne s ciljem povećanja nacionalnog blagostanja. Prema tome, temeljni cilj rada je istražiti i ocijeniti učinkovitost djelovanja i financijskog stanja jedinica javnog sektora u Republici Hrvatskoj na središnjoj, regionalnoj $i$ lokalnoj razini za razdoblje od 2011. do 2017. Rezultati istraživanja mogu doprinijeti detektiranju problemskih područja djelovanja pojedinih jedinica, te usmjeravanju napora $u$ njihovo rješavanje kao $i$ podlogu za provođenje istraživanja povezanosti $i$ doprinosa djelovanja javnog sektora u povećanju nacionalnog blagostanja u Republici Hrvatskoj. Analiza jeprovedena nauzorku od 80 proračunskih korisnika za sedmogodišnje razdoblje. Za obradu podataka korištene su opisne mjere brojčane statistike, korelacijska analiza, odgovarajući neparametarski testovi (npr. Kruskal-Wallis test) te analiza omeđivanja podataka. Dobiveni rezultati upućuju na postojanje razlika u učinkovitosti i financijskom stanju proračunskih korisnika u ovisnosti o razini upravljanja. Također, 
financijskim pokazateljima moguće je dobiti jasniju ocjenu po segmentima djelovanja proračunskih korisnika u odnosu na jedinstveni pokazatelj djelotvornosti. Istraživanjem se došlo do zaključka da su veći proračunski korisnici učinkovitiji $i$ imaju bolje financijsko stanje od manjih korisnika te da nema povezanosti između razine djelotvornosti $i$ indeksa razvijenosti geografskog područja djelovanja proračunskog korisnika.

Ključne riječi: proračunski korisnici, učinkovitost i djelotvornost, financijsko stanje, financijski pokazatelji, analiza omeđivanja podataka, indeks razvijenosti

JEL: H21, H7, M41, M48

\section{UVOD}

Gospodarski rast pojedine države, koji se uobičajeno mjeri stopom rasta BDP-a, rezultat je kombinacije više različitih čimbenika, a neki od njih su direktna strana ulaganja (Upreti, 2015; Bogdan, 2009), razvijenost financijskog sustava (Delić i Rogić Dumančić, 2016), zaduženost, izvoz, razina obrazovanja, starost stanovništva, korupcija, tehnološka razvijenost, kao i učinkovitost upravljanja javnogsektora (Djapou, Chimene i Ndedi, 2017; Upreti, 2015; Anyanwu, 2014). Prema Zakonu o proračunu, javni sektor su „državni proračun, jedinice lokalne i područne (regionalne) samouprave, proračunski i izvanproračunski korisnici državnog proračuna i proračuna jedinica lokalne i područne (regionalne) samouprave“ (članak 3.). Nadalje, Zakonom je definirano da je ,jedinica lokalne i područne (regionalne) samouprave jest općina, grad i županija čija tijela obavljaju funkcije, izvršavaju zadaće i donose programe propisane zakonom i odlukama donesenima na temelju zakona, za što se sredstva osiguravaju u njihovu proračunu“ (članak 3.), odnosno ,proračunski korisnici su državna tijela, ustanove, vijeća manjinske samouprave, proračunski fondovi i mjesna samouprava čiji se rashodi za zaposlene i/ili materijalni rashodi osiguravaju u proračunu“ (članak 3.). Proračunski korisnici obveznici su vođenja poslovnih knjiga i financijskog izvještavanja u skladu s Pravilnikom o proračunskom računovodstvu i računskom planu.

Kao što je ranije istaknuto, jedan od čimbenika gospodarskog rasta je učinkovitost upravljanja u javnom sektoru. Važnu ulogu u usmjeravanju upravljanja javne uprave ima Organizacija za ekonomsku suradnju i razvoj (engl. TheOrganisation for Economic Co-operationand Development - OECD) koja definira upravljanje proračunom i temeljna načela suvremenog pristupa upravljanja proračunom (engl. modernbudgetarygovernance). Upravljanje proračunom je „proces oblikovanja 
godišnjeg proračuna, nadzora njegove implementacije i osiguranja usklađenosti s javnim ciljevima“ (OECD, web) Ciljevi proračunskog sustava moraju se ostvarivati na svrhovit, održiv i trajan način (OECD, 2015, 5). Posebnu važnost u suvremenom upravljanju proračuna imaju transparentnost i integritet. Transparentnost podrazumijeva otvorenu komunikaciju prema građanima o tome kako je novac prikupljen i na što je potrošen (OECD, 2017b, 9) dok se integritet odnosi na „dosljedno usklađivanje i pridržavanje zajedničkih etičkih vrijednosti, načela i normi, održavanje i stavljanje prioriteta javnih nad privatnim interesima u javnom sektoru.“ (OECD, 2017a, web). Pitanje transparentnosti u Republici Hrvatskoj ispunjava se javnim objavama proračuna, financijskih izvještaja i ostalih relevantnih informacija na Internet stranicama pojedinog proračunskog korisnika dok se integritet treba ostvarivati primjenom ogovarajuće računovodstvene regulative kao što su zakonski propisi i računovodstveni standardi, zatim uspostavljanjem internih kontrola i funkcija unutarnje revizije kao i državnom revizijom.

Važan aspekt suvremenog upravljanja proračunom ima koncept odgovornosti (engl. accountability) prema kojem djelatnici javne uprave trebaju biti odgovorni za svrhovitu i djelotvornu raspodjelu proračunskih sredstava (OECD, 2017b, 9). Prema tome, javna uprava mora biti učinkovita (engl. performance) što uključuje ekonomično (engl. economy), djelotvorno (engl. efficiency) i svrhovito (engl. effectiveness) djelovanje u svim aktivnosti.

\section{PREGLED LITERATURE}

Kao što je ranije istaknuto, učinkovito djelovanje proračunskih korisnika podrazumijeva konvergenciju ekonomičnog, djelotvornog i svrhovitog djelovanja. U tome smislu, važno je razumijevanje ključnih pojmova. „Načelo ekonomičnosti podrazumijeva svođenje troškova resursa na najmanju moguću mjeru. Korišteni resursi trebaju biti na raspolaganju pravodobno, u odgovarajućoj količini i uz odgovarajuću kvalitetu te po najboljoj cijeni. Načelo djelotvornosti podrazumijeva najbolje moguće iskorištavanje raspoloživih resursa. Vezano je uz odnos korištenih resursa i izlaznih vrijednosti ostvarenih u pogledu količine, kvalitete i rokova. Načelo svrhovitosti odnosi se na ispunjavanje postavljenih ciljeva i postizanje predviđenih rezultata." (INTOSAI, web, prijevod na hrvatski, 3) Relativno je mali broj istraživanja usmjerenih sveukupnoj ocjeni učinkovitosti djelovanja (Ozkul i Alkan, 2017; Odero, 2017; Hrůza, 2015; Ramsey, 2013; Kablan, 2013;Ramlidrugi, 2013;Suarez, Lesneski i Denison, 2011;Alibegović i Blažević, 2010; Phatudi, 2010;Roje, 2008;Brown, 1993), a veliki broj istraživanja bavi se analizom djelotvornosti, najčešće jedinica lokalne samouprave, primjenom metode analize 
omeđivanja podataka (Šegota, Cerović i Maradin, 2017; Lovre i Jotić, 2016; Vitezić, Šegota i Setnikar-Cankar, 2016; Bađun, Pribičević i Deskar-Škrbić, 2014; Domljan, 2013;Obadići Aristovnik, 2011; Sever, Drezgić i Blažić, 2011; Jafarov i Gunnarsson, 2008;), a postoje i istraživanja o kreditnom riziku proračunskih korisnika (Vlah Jerić i Primorac, 2017). Pored znanstvenika, analizom djelovanja proračunskih korisnika bavile su se i međunarodniinstituti koji su oblikovali pokazatelje koje pored informacija iz financijskih izvještaja uključuju i makroekonomske indikatore (PSAB, 2010; ICMA, 2003; CICA, 1997). Na taj način izravno se uspoređuje djelovanje pojedinog proračunskog korisnika $\mathrm{s}$ određenom varijablom razvoja toga područja djelovanja. I kompleksniji pristupi ocjene primjenom matematičkih metoda, kao što je analiza omeđivanja podataka, pored rashoda kao izlazne varijable, koriste makroekonomske indikatore kao ulazne varijable. Iako se radi o važnim aspektima razmatranja djelovanja proračunskog korisnika, postavlja se pitanje ocjene djelovanja same jedinice, neovisno o okruženju. Promatrano na taj način, važnu ulogu mogu imati financijski pokazatelji koji se izračunavaju isključivo temeljem rezultata i stanja same jedinice (Ježovita, 2018). Mustafin i Vavrek, (2018) u svome radu daju pregled mogućih metoda za ocjenu djelotvornosti koje su klasificirali u pet skupina: (1) metode koje se temelje na jednom indikatoru kao što su financijski pokazatelji, (2) metode koje se temelje na više kriterija kao što su rangovi, ponderirani pokazatelji, (3) komparativne metode kao što je usporedba različitih pokazatelja, (4) upravljačke metode kao što su benchmarking, SWOT analiza, mapa uravnoteženih ciljeva, i (5) ostale metode (Mustafini Vavrek, 2018, 170-172). U kontekstu pripremljenog pregleda literature autori financijske pokazatelje svrstavaju u metode koje se temelje na jednom indikatoru, a metode ocjene djelotvornosti kao što je analiza omeđivanja podataka u upravljačke metode.

Kao jedan od prvih autora koji se bavio pitanjem djelovanjem jedinica javnog sektora,Brown (1993) oblikuje test za ocjenu financijskog stanja općina do 100.000 stanovnika temeljem kojeg se učinkovitost ocjenjuje međusobnom usporedbom rezultata testa analiziranih jedinica (Brown, 1993, 24). Roje (2008) u svome radu daje pregled pokazatelja za proračunske korisnike zemalja Sjeverne Amerike i Australije kao okosnice dobre prakse za primjenu u Republici Hrvatskoj (Roje, 2008, 28-31).Sever i Žager (2008) navode da je pored uobičajene analize poslovanja u privatnom sektoru važno provoditi i analizu financijskih izvještaja jedinica u javnom sektoru te u tome smislu navode mogućnosti i ograničenja primjene postojećeg seta financijskih pokazatelja kod različitih subjekata javnog sektora kao što su proračunski korisnici, javna poduzeća i neprofitne organizacije.Alibegović i Blažević (2010) bave se pitanjem uspješnosti jedinica lokalne samouprave vezanih uz problematiku povezivanja proračunskih rashoda $\mathrm{s}$ postignutim konkretnim rezultatima. Prema autorima, u kontekstu djelovanja 
jedinica lokalne samouprave važno je „unapređenje procesa planiranja, izvršenja, praćenja i nadzora proračunskih rashoda radi povećanja racionalnosti u trošenju javnih sredstava uz istovremeno pružanje javnih usluga na najvišoj mogućoj razini kvalitete“ (Alibegović i Blažević, 2010, 632). Phatudi (2010) analizira financijsku održivost općina u pokrajini North West za razdoblje od 2006. do 2009. godine primjenom financijskih pokazatelja koji se temelje na prihodima, imovini i obvezama. Autor zaključuje da općina ne može biti uspješna bez odgovarajućih financijskih resursa i financijskog menadžmenta pri kojem pozornost treba biti usmjerena operativnom i kapitalnom financiranju (Phatudi, 2010, 57). Suarez, Lesneski, i Denison (2011) pokazatelje sagledavaju kao pokazatelje prihoda, pokazatelje rashoda, pokazatelje kritičnih projekata i statistika zajednice, a koje su primijenili na primjeru lokalnih zdravstvenih ustanova s ciljem stvaranja svijesti o važnosti analize proračunskih korisnika radi kvalitetnije politike upravljanja raspoloživim javnim sredstvima (Suarez, Lesneski i Denison, 2011, 422-423). Kablan (2013) analizira financijske izvještaje jedinica lokalne samouprave čime potvrđuje mogućnost primjene seta financijskih pokazatelja za profitni sektor za primjenu kod proračunskih korisnika. „Svrha javnih institucija razlikuje se od svrhe poduzeća u privatnom sektoru. Dok je svrha poduzeća privatnog sektora maksimizacija dobiti, svrha javnih institucija je omogućiti učinkovito, produktivno i ekonomično korištenje resursa i usluga za društvo u cjelini.“ (Kablan, 2013, 7586). Ramsey (2013) daje pregled najčešće korištenih pokazatelja u slučaju proračunskih korisnika gdje se kao važni pokazatelji izdvajaju omjer ukupnih prihoda i broja stanovnika koji daje informaciju o prihodima po stanovniku za promatranog proračunskog korisnika, pokazatelji koji su u svome izračunu vezani za neki aspekt obveza subjekta te općenito pokazatelji vezani za namjenu rashoda(Ramsey, 2013, 8-9).Ramli i drugi (2013) istražuju korisnost smjernica dvije grupe financijskih pokazatelja u procjeni financijskog stanja vjenčanih zaposlenika javnog sektora u Maleziji usporedbom pokazatelja štednje i zaduženosti 415 zaposlenika prikupljenih anketnim upitnikom tijekom 2008 . godine. Rezultati ukazuju na financijsko blagostanje onih zaposleni kod kojih je više zaposlenih u kućanstvu te da je iznos štednje općenito nezadovoljavajući (Ramli, Masud, Haron, Othman, Awang i Md Sum, 2013, 5). Takvi rezultati mogu biti dobar indikator općenitih nedostataka u gospodarskom rastu pojedine države.Odero (2017) istražuje financijsku uspješnost općina u Karibibu za razdoblje od 2004. do 2008. godine primjenom pokazatelja profitabilnosti, likvidnosti i aktivnosti. Rezultati istraživanja ukazuju na nedostatnu uspješnost $u$ pogledu financijskog upravljanja djelovanjem općina (Odero, 2017, 56). Autor je utvrdio značajnu ovisnost upravljanja, usklađenosti s regulativom i financijske uspješnosti, kao i negativnu povezanost između financijske uspješnosti i oslanjanja na potpore i transfere, kao i značajnu ovisnost financijske uspješnosti i veličine općine, gdje veće općine imaju veću uspješnost od manjih općina (Odero, 2017, 
72).Ozkul i Alkan (2017)ocjenjivali su financijsko stanje općina u Turskoj primjenom 11 financijskih pokazatelja, primjerice likvidnost, solventnost proračuna, dugoročna solventnost, solventnost na razini usluge (Ozkul i Alkan, 2017, 159). Autori su zaključili da bi za iscrpniju analizu proračunski korisnici trebali objavljivati detaljnije informacije (Ozkul i Alkan, 2017, 172).

S druge strane, brojni autori su istraživali djelotvornost javnog sektora primjenom metode analize omeđivanja podataka kao najkorištenijim pristupom za ocjenu djelotvornosti u znanosti, a i u praksi. Jafarov i Gunnarsson (2008) primjenom analize omeđivanja podataka utvrdili su postojanje nedjelotvornosti socijalnog trošenja u Republici Hrvatskoj koje je prvenstveno rezultat neadekvatnog povrata troškova povezanih sa zdravstvenim i obrazovnim uslugama, manjkavostima financijskih mehanizama i institucionalnih dogovora, slabom konkurencijom u pružanju socijalnih usluga i slabostima u usmjeravanju naknada (Jafarov i Gunnarsson, 2008, 289) „Ključni je problem kako smanjiti omjer troškova javne uprave u odnosu na BDP, uključujući postojeću kvalitetu socijalnih usluga bez nepotrebne žrtve u kvaliteti.“ (Jafarov i Gunnarsson, 2008, 290) Povezano s obrazovnim uslugama,Obadić i Aristovnik (2011) istražuju djelotvornost višeg obrazovanja u Hrvatskoj i Sloveniji primjenom analize omeđivanja podataka. Analiza je provedena za razdoblje od 1999. do 2007. godine gdje su ulazne varijable u modelu tercijarni troškovi po studentu kao postotak BDP-a po stanovniku, a izlaznevarijable, tj. upis u tercijarnu razinu obrazovanja (\% bruto), radnu snagu s tercijarnim obrazovanjem (\% od ukupnog broja) i nezaposlene $\mathrm{s}$ tercijarnim obrazovanjem (\% ukupne nezaposlenosti) u trideset sedam zemalja uključeni su u analizu (odabrane nove članice EU i zemlje OECD) (Obadić i Aristovnik, 2011, 371). Rezultati ukazuju na značajnu nedjelotvornost troškova u višem obrazovanju u Republici Hrvatskoj, dok rezultati za Sloveniju ukazuju na veću djelotvornost upravljanja troškovima (Obadići Aristovnik, 2011, str. 374).Sever, Drezgić i Blažić (2011) istraživali su povezanost trošenja u javnoj upravi s rastom i strukturom BDP-a u Republici Hrvatskoj za dvadesetogodišnje razdoblje analizom troškovnih stavki proračuna (Sever, Drezgići Blažić, 2011, 311). Prema dobivenim rezultatima kapitalni troškovi imaju pozitivan učinak na gospodarski rast (kratkoročno i dugoročno), a s druge strane varijable vezane uz trenutačnu potrošnju, naknade zaposlenih i subvencije u svim slučajevima dugoročno pokazuju negativan utjecaj na BDP, također subvencije u svim specifikacijama u kratkom roku povećavaju BDP, dok dugoročno utječu negativno (Sever, Drezgić i Blažić, 2011, 316).Domljan (2013) istražuje mogućnosti povećanja djelotvornosti usluga lokalne vodoopskrbe na uzorku od 38 jedinica iz Bosne i Hercegovine za razdoblje 2000.-2009. godine primjenom analize omeđivanja podataka s tri ulazne varijable, dvije izlazne i dvije varijable okruženja (Domljan, 2013, 81). Rezultati istraživanja ukazuju na nedjelotvornost lokalne 
vodoopskrbe te da „,ne postoje regulatori vodoopskrbe u BiH niti slična tijela koja bi korištenjem razvijenih, uobičajeno korištenih kvantitativnih metoda ocjene efikasnosti, ocjenjivala efikasnost vodoopskrbe u BiH. S druge strane, regulatori vrše svoju zadaću prikladno samo onda kad korištenjem nekoliko razvijenih kvantitativnih metoda ocjenjuju efikasnost djelovanja operatera, i to za niz od nekoliko godina“ (Domljan, 2013, 208).Bađun, Pribičević i Deskar-Škrbić (2014) istražuju ograničenja gospodarskog rasta Hrvatske povezane s javnom upravom. Autori kao potencijalna ograničenja rastu sučeljavaju veličinu javne uprave i djelotvornost. Primjenom analize omeđivanja podataka autori su utvrdili efikasnost hrvatske javne uprave većom od prosjeka članica Europske unije $(0,802>0,736)$ što se još uvijek ne može smatrati djelotvornim (Bađun, Pribičevići Deskar-Škrbić, 2014, 302). Kao jedan od razloga nedjelotvornosti, autori ističu korupciju, a njihovi rezultati potvrđuju prethodna istraživanja da zemlje s većim javnim sektorom teže djelotvornijem upravljanju (Bađun, Pribičević i Deskar-Škrbić, 2014, 317).Vitezić, Šegota i Setnikar-Cankar (2016) navode da je djelotvornost jedno od najvažnijih načela u sustavu javnog zdravstva koje se ispunjava s racionalnom potrošnjom uz potrebu povećanja kvalitete. Autori su istraživali 12 zdravstvenih jedinica za dvogodišnje razdoblje primjenom analize omeđivanja podataka te došli do zaključka da se primijenjena metoda može koristiti u procjenjivanju djelotvornosti usluga u zdravstvenom sustavu te da može biti dobra podrška čelnicima tih jedinica (Vitezić, Šegota i Setnikar-Cankar, 2016, 27).Lovre i Jotić (2016) primjenom metode analize omeđivanja podataka istražuju djelotvornost javnog sektora $u$ zemljama Europske unije s naglaskom na Srbiju. Rezultati istraživanja ukazuju na općenitu nedjelotvornost javnog sektora zemalja uključenih u analizu gdje Srbija ima najlošije rezultate (Lovre iJotić, 2016, 156).Šegota, Cerović i Maradin (2017) istraživali su djelotvornost komunalnih poduzeća u Republici Hrvatskoj primjenom analize omeđivanja podataka gdje su zarade prije kamata, poreza i amortizacije izlazna varijabla, a ukupna imovina, materijalni troškovi, troškovi zaposlenih i broj stanovnika su ulazne varijable modela (Šegota, Cerović i Maradin, 2017, 552). Prema dobivenim rezultatima istraživanja osam poduzeća može se smatrati relativno djelotvornima, a njih 12 je ocjenjeno nedjelotvornima (Šegota, Cerović i Maradin, 2017, 559).Vlah Jerić i Primorac (2017) testiraju uspješnost lokalne samouprave u Republici Hrvatskoj kako bi odredili njihov kreditni rizik primjenom tri metode: umjetna neuronska mreža, hibridna umjetna neuronska mreža i pristup genetskom algoritmu, i Tobit regresijski pristup (Vlah Jerić i Primorac, 2017, 193). Istraživanje obuhvaća svih 556 hrvatskih općina i gradova za 2008. godinu gdje je kreditni rizik aproksimiran kao omjer dospjelih i ukupnih obveza, a prosječna vrijednost pokazatelja je 0,0930 (Vlah Jerić i Primorac, 2017, 195). 


\section{OBLIKOVANJE HIPOTEZA, METODOLOGIJA ISTRAŽIVANJA I UZORAK}

Provedeni pregled literature potvrđuje važnost ocjene djelovanja jedinica u javnom sektoru. U tome kontekstu najviše je pozornosti usmjereno raspodjeli raspoloživih sredstava, najčešće mjereno rashodima, te povezanosti $s$ različitim makroekonomskim indikatorima. Najveći broj autora upravo djelotvornost upravljanja javnim sredstvima izravno povezuje s postignutim blagostanjem i gospodarskim razvojem pojedine regije, zemlje i slično. Vezano uz to može se oblikovati istraživački problem koji uključuje pitanje koliko su jedinice javnog sektora u Republici Hrvatskoj djelotvorne i učinkovite u upravljanju proračunskom sredstvima s ciljem povećanja nacionalnog blagostanja.

Kako bi se istražio navedeni problem, cilj rada je analizirati i ocijeniti učinkovitost djelovanja i financijskog stanja jedinica javnog sektora u Republici Hrvatskoj na središnjoj, regionalnoj i lokalnoj razini za razdoblje od 2011. do 2017. godine te usporediti i utvrditi razlike u djelotvornosti i učinkovitosti djelovanja na pojedinoj razini. Ocjena će se provoditi primjenom seta financijskih pokazatelja prilagođenih specifičnostima strukturi i sadržaju financijskih izvještaja proračunskih korisnika (Ježovita, 2018) te primjenom analize omeđivanja podataka u kojoj će i ulazne i izlazne varijable biti informacije iz financijskih izvještaja. Tako provedenom analizom moći će se usporediti dvije metode te će se moći ocijeniti ispravnost i korisnost primjene pojedinačnih financijskih pokazatelja u usporedbi s ocjenom djelotvornosti pomoću analize omeđivanja podataka kao najpoznatijeg i dokazanog alata za ocjenu djelotvornosti jedina javnog sektora.Nadalje, najveći broj radova svoje istraživanje temelji ili na nacionalnoj razini ili na lokalnoj razini. U tome kontekstu, može se postaviti pitanje o razlikama u djelotvornosti proračunskih korisnika u odnosu na razinu upravljanja, primjerice u Republici Hrvatskoj, može se govoriti o jedinicama lokalne, regionalne ili središnje razine, i o povezanosti te djelotvornosti prema razinama s razvijenosti geografskog područja na kojem jedinica djeluje. Navedeni ciljevi istraživanja rezultiraju s tri istraživačke hipoteze:

H1: Postoje statistički značajne razlike u učinkovitosti i financijskom stanju između jedinica na različitim razinama ustrojstva u Republici Hrvatskoj

H2: Razvijenost pojedinog geografskog područja uvjetovana je djelotvornošću upravljanja raspoloživim prihodima toga područja

H3: Primjenom financijskih pokazatelja može se preciznije odrediti financijsko stanje i učinkovitost djelovanja proračunskih korisnika nego primjenom jedinstvenog pokazatelja djelotvornosti.

Opća država ili javna uprava uključuju središnju državnu, regionalnu vlast i lokalnu vlast. U Republici Hrvatskoj ukupno je 3715 (Ministarstvo financija, web) 
proračunskih i izvanproračunskih korisnika koji sačinjavaju opću državu, a uključuju (Bejaković,.Vukšići Bratić, 2011, 99-125):

- središnju državu:

- proračunski korisnici državnog proračuna (643 obveznika)

- izvanproračunski korisnici državnog proračuna ( 8 obveznika)

- regionalnu i lokalnu vlast:

- proračunski korisnici proračuna jedinica lokalne i područne (regionalne) samouprave (3044 obveznika)

- izvanproračunski korisnici jedinica lokalne i područne (regionalne) samouprave (20 obveznika).

U Republici Hrvatskoj ustrojeno je ukupno 555 jedinica lokalne samouprave od kojih je 428 općina, 127 gradova i 20 jedinica područne (regionalne) samouprave (Ministarstvo uprave, web). Istraživanje uključuje analizu 34 jedinice na lokalnoj razini, a odnose se na gradove koji su obveznici ustrojavanja unutarnje revizije, što znači da se radi o 34 najveća grada u Republici Hrvatskoj. Pored toga, analizom je obuhvaćeno svih 20 jedinica područne (regionalne) samouprave, tj. svih 20 županija i Grad Zagreb koji se jedinstveno razmatra kao jedinica regionalne i lokalne samouprave jer ima poseban status grada i županije. Prema tome, od ukupno 576 jedinica lokalne i područne (regionalne) samouprave istraživanjem je obuhvaćeno 9,55\% najvećih jedinica. Pored lokalne i regionalne razine, analizom je obuhvaćena i središnja razina koja predstavlja državnu upravu. Tijela državne uprave u Republici Hrvatskoj su ministarstva (20), središnji državni uredi (5), državne upravne organizacije (7) i uredi državne uprave u županijama (20) (Ministarstvo uprave, web). Istraživanje uključuje 25 (26) jedinica na središnjoj razini. Sveukupno promatrano istraživanje obuhvaća analizu 80 jedinica javnog sektora za šestogodišnje razdoblje od 2012. do 2017. godine (2016. i 2017. godine uključuju analizu 81 jedinice uslijed ustrojavanja novog Ministarstva državne imovine).

Za potrebe pripreme rada, provedbe analize i testiranja hipoteza korištene su deskriptivna metoda i metoda analize. Podaci su analizirani primjenom metoda opisne statistike, primjenom odgovarajućih neparametarskih testova (KruskalWallis), korelacijskom analizom i analizom omeđivanja podataka.Podaci potrebni za analizu dobiveni su putem elektroničke pošte iz Registra godišnjih financijskih izvještaja Financijske agencije, uz suglasnost Ministarstva financija. 


\section{REZULTATI ISTRAŽIVANJA}

Proračunski korisnici uključeni $u$ analizu podijeljeni su na četiri razine upravljanja. Lokalna razina uključuje analizirane gradove, lokalna i regionalna razine uključuje Grad Zagreb, regionalnu razinu čine županije, dok su jedinice kao što su ministarstva ili državni uredi obuhvaćeni središnjom razinom.

Tablica 1 Deskriptivna statistika ukupne imovine proračunskih korisnika prema razinama ustrojstva u Republici Hrvatskoj za 2017. godinu

\begin{tabular}{|l|r|r|r|r|r|}
\hline & \multicolumn{1}{|c|}{$\sum$} & \multicolumn{1}{c|}{ MIN } & \multicolumn{1}{c|}{ AS } & \multicolumn{1}{c|}{ SD } & \multicolumn{1}{c|}{ MAX } \\
\hline $\begin{array}{l}\text { Lokalna } \\
\text { razina }\end{array}$ & 61.975 .033 .269 & 223.128 .652 & 1.822 .795 .096 & 2.265 .404 .141 & 8.968 .439 .270 \\
\hline $\begin{array}{l}\text { Regionalna i } \\
\text { lokalna } \\
\text { razina }\end{array}$ & 17.981 .871 .522 & 17.981 .871 .522 & 17.981 .871 .522 & & 17.981 .871 .522 \\
\hline $\begin{array}{l}\text { Regionalna } \\
\text { razina }\end{array}$ & 4.193 .608 .878 & 36.553 .685 & 209.680 .444 & 153.413 .089 & 561.565 .337 \\
\hline $\begin{array}{l}\text { Središnja } \\
\text { razina }\end{array}$ & 139.503 .543 .598 & 205.716 & 5.365 .520 .908 & 15.979 .763 .602 & 70.589 .319 .736 \\
\hline \multicolumn{1}{|c|}{$\sum$} & 223.654 .057 .267 & - & - & & \\
\hline
\end{tabular}

Legenda: $\Sigma$ - zbroj; MIN - minimalna vrijednost; $A S$ - aritmetička sredina; SD standardna devijacija; MAX-maksimalna vrijednost

Izvor: Izračun autora temeljem podataka dobivenim elektroničkom poštom iz Registra godišnjih financijskih izvještaja, Financijska agencija

Iako promatrano prema razinama Grad Zagreb (Regionalna i lokalna razina) ima najveću vrijednost ukupne imovine, pojedinačno promatrano, u 2017. godinu najveću vrijednost ukupne imovine ima Ministarstvo obrane sa 70,6 milijardi kuna, zatim Ministarstvo državne imovine s 45,3 milijarde kuna, dok je na trećem mjestu Grad Zagreb s 18 milijardi kuna. Sveukupno promatrano, analizirani uzorak obuhvaća 223,7 milijardi kuna imovine (Tablica 1). Usporedbe radi, bruto domaći proizvod u tekućim tržišnim cijenama u 2017. godini bio je 365,6 milijardi kuna (Državni zavod za statistiku, web). Najmanju i najveću vrijednost ukupne imovine imaju jedinice na središnjoj razini. Najmanju vrijednost ukupne imovine u 2017. godini ima Ured za unutarnju reviziju (205.716 kuna), a najveću, ranije spomenuto, Ministarstvo obrane (70,6 milijardi kuna). S obzirom na vrijednosno veliki raspon u vrijednosti ukupne imovine kod jedinica središnje razine, očekivano na toj razini postoji najveća disperzija podataka s prosječnim odstupanjem od prosjeka od 16 milijardi kuna uz prosječnu vrijednost ukupne imovine od 5,4 milijarde kuna. Prema vrijednosti ukupne imovine najmanji grad uključen u analizu je Grad Trogir (223 milijuna kuna), a najveći je Grad Pula (8,97 milijarde kuna). Najmanju vrijednost ukupne imovine u 2017. godini ima Ličko-senjska županija (36,6 milijuna kuna), a najveću Primorsko-goranska županija (561,6 milijuna kuna). 
Tablica 2: Deskriptivna statistika ukupnih prihoda i primitaka proračunskih korisnika prema razinama ustrojstva u Republici Hrvatskoj za 2017. godinu

\begin{tabular}{|l|r|r|r|r|r|}
\hline & \multicolumn{1}{|c|}{$\sum$} & \multicolumn{1}{c|}{ MIN } & \multicolumn{1}{c|}{ AS } & \multicolumn{1}{c|}{ SD } & \multicolumn{1}{c|}{ MAX } \\
\hline Lokalna razina & 6.743 .660 .024 & 33.576 .810 & 198.342 .942 & 176.829 .252 & 840.386 .835 \\
\hline $\begin{array}{l}\text { Regionalna i } \\
\text { lokalna razina }\end{array}$ & 6.940 .332 .803 & 6.940 .332 .803 & 6.940 .332 .803 & & 6.940 .332 .803 \\
\hline Regionalna razina & 4.099 .228 .371 & 114.134 .209 & 204.961 .419 & 90.756 .714 & 462.778 .359 \\
\hline Središnja razina & 43.005 .912 .514 & 1.836 .102 & 1.654 .073 .558 & 2.528 .467 .560 & 9.737 .233 .303 \\
\hline \multicolumn{1}{|c|}{-} & - & & & - \\
\hline
\end{tabular}

Legenda: $\Sigma$ - zbroj; MIN - minimalna vrijednost; $A S$ - aritmetička sredina; $S D$ standardna devijacija; MAX-maksimalna vrijednost

Izvor: Izračun autora temeljem podataka dobivenim elektroničkom poštom iz Registra godišnjih financijskih izvještaja, Financijska agencija

Ukupni prihodi i primici državnog proračuna Republike Hrvatske u 2017. godini bili su 165,4 milijarde kuna (Ministarstvo financija, web). Istraživanje uključuje analizu korisnika državnog proračuna koji su 2017. godine ostvarili ukupno 60,8 milijardi kuna ukupnih prihoda i primitaka što čini gotovo $37 \%$ državnog proračuna (Tablica 2). Kao i u slučaju imovine, najmanju vrijednost preraspodijeljenih prihoda i primitaka ima korisnik na središnjoj razini, Ured za unutarnju reviziju (1,8 milijuna kuna), a najveću Ministarstvo znanosti i obrazovanja (9,7 milijardi kuna). Prema vrijednosti ukupnih prihoda i primitaka najmanji grad je Grad Krapina (33,6 milijuna kuna), a najveći, osim Grada Zagreba, je Grad Split (840,4 milijuna kuna); nadalje, najmanja županija je Požeško-slavonska županija (114 milijuna kuna), a najveća je Splitsko-dalmatinska županija (462,8 milijuna kuna).

Tablica 3: Deskriptivna statistika prosječnog broja zaposlenih (u tijelima i kod korisnika) proračunskih korisnika prema razinama ustrojstva u Republici Hrvatskoj za 2017. godinu

\begin{tabular}{|l|r|r|r|r|r|}
\hline & \multicolumn{1}{|c|}{$\sum$} & \multicolumn{1}{c|}{ MIN } & \multicolumn{1}{c|}{ AS } & \multicolumn{1}{c|}{ SD } & \multicolumn{1}{c|}{ MAX } \\
\hline Lokalna razina & 8.136 & 41 & 239 & 203 & 1.012 \\
\hline Regionalna i lokalna razina & 2.879 & 2.879 & 2.879 & & 2.879 \\
\hline Regionalna razina & 3.126 & 43 & 156 & 123 & 491 \\
\hline Središnja razina & 124.917 & 11 & 4.805 & 14.572 & 70.427 \\
\hline \multicolumn{1}{|c|}{$\sum$} & 139.058 & & & & \\
\hline
\end{tabular}

Legenda: $\Sigma$ - zbroj; MIN - minimalna vrijednost; $A S$ - aritmetička sredina; $S D$ standardna devijacija; MAX-maksimalna vrijednost

Izvor: Izračun autora temeljem podataka dobivenim elektroničkom poštom iz Registra godišnjih financijskih izvještaja, Financijska agencija

Istraživanje obuhvaća proračunske korisnike koji zapošljavaju 139 tisuća zaposlenih. Najveći broj zaposlenih imaju tijela središnje razine i to u prosjeku 4.805 osoba s prosječnim odstupanjem od prosjeka od 14.572 osobe (Tablica 3). 
Velika disperzija rezultat tijela različite veličine na središnjoj razini, od Ureda za unutarnju reviziju koji zapošljava svega 11 osoba do Ministarstva znanosti i obrazovanja sa 70.427 zaposlenih u 2017. godini. Na lokalnoj razini, najveći broj zaposlenih u 2017. godini imao je Grad Šibenik s 1.012 osoba, a najmanje Grad Labin s 41 zaposlenikom. Promatrano na regionalnoj razini najmanje zaposlenih ima Požeško-slavonska županija (43), a najviše Istarska županija (491).

Prema svim promatranim parametrima veličine zaključuje se da tijela državne uprave imaju najveći udio u vrijednosti ukupne imovine, raspoloživih ukupnih prihoda i primitaka kao i broja zaposlenih. Nadalje, jedinice regionalne (područne) samouprave mogu se smatrati najmanjima dok Grad Zagreb kao zasebna jedinica prednjači i pred većinom tijela državne uprave. Nedvojbeno se može zaključiti kako postoje značajne razlike u veličini jedinica proračunskih korisnika podijeljenih prema razinama ustrojstva u Republici Hrvatskoj u 2017. godini. Rezultati provedenog neparametarskogKruskal-Wallis testa pokazuju postojanje razlika između distribucija u odnosu na razinu ustrojstva za sve tri promatrane varijable (p vrijednost .000) (Tablica 4). Dobiveni rezultati potvrđuju potrebnu analize djelotvornosti prema različitim razinama upravljanja.

Tablica 4: Rezultati provedenog testiranja jednakosti distribucija ukupne imovine, ukupnih prihoda i primitaka i prosječnog broja zaposlenih prema ustrojstvenim

Test Statistics ${ }^{a, b}$ razinama u Republici Hrvatskoj

\begin{tabular}{|l|r|r|r|}
\hline & Ukupna imovina & \multicolumn{1}{|c|}{$\begin{array}{c}\text { Ukupno prihodi i } \\
\text { primici }\end{array}$} & \multicolumn{2}{c|}{$\begin{array}{c}\text { Prosječan broj } \\
\text { zaposlenih }\end{array}$} \\
\hline Kruskal-Wallis H & 174.594 & 51.751 & 65.255 \\
\hline df & 3 & 3 & 3 \\
\hline Asymp. Sig. & .000 & .000 & .000 \\
\hline
\end{tabular}

a. Kruskal Wallis Test

b. GroupingVariable: Razina

\section{Izvor: Izračun autora}

Nakon utvrđivanja da postoje razlike u veličini tijela na različitim razinama upravljanja, tj. jedinice lokalne samouprave raspolažu sa statistički značajno manje ukupne imovine i ukupnih prihoda i primitaka u odnosu na tijela državne uprave. Također, može se zaključiti da, izuzev Grada Zagreba koji se izdvaja po veličini svih varijabli, jedinice lokalne i regionalne samouprave raspolažu sa sličnom razinom ukupnih prihoda i primitaka, ali jedinice lokalne razine u prosjeku raspolažu sa šest puta više ukupne imovine. Između ukupnih prihoda i primitaka i prosječnog broja zaposlenih analiziranih jedinica postoji statistički značajna srednje jaka pozitivna povezanost s obzirom da je Spearmanov koeficijent korelacije .597 (razina signifikantnosti 1\%). Takav rezultat može označavati usporednost rezultata veličine pojedine razine, i jedinica te razine, u odnosu na odgovornosti te površinu za koju su odgovorni. 
Samim time, u ocjeni djelotvornosti proračunskih korisnika nedovoljno je istraživati usporedbu pokazatelja veličine i razvijenosti pojedinih jedinica $\mathrm{s}$ raspoloživom imovinom, prihodima i primicima ili brojem zaposlenih, već je u analizu potrebno uključiti određene financijske pokazatelje kojima će se moći ocijeniti učinkovitost $\mathrm{i}$ financijsko stanje proračunskih korisnika na pojedinoj razini.

Pokazatelji ekonomičnosti i svrhovitosti mogu se smatrati pokazateljima za ocjenu učinkovitosti djelovanja proračunskih korisnika. Prvom skupinom pokazatelja ocjenjuje se koliko su proračunski korisnici djelotvorni u raspodjeli proračunskih prihoda, a pokazateljima svrhovitosti ocjenjuje se koliko su uspješni u ostvarivanju ciljeva i predviđenih rezultata (Ježovita, 2018, 81-83). Za potrebe istraživanja izabrana su četiri pokazatelja za ocjenu učinkovitosti djelovanja proračunskih korisnika, a to su: ekonomičnost poslovanja, ekonomičnost upravljanja dugom, stopa viška/manjka te omjer obračunatih i naplaćenih prihoda (formule za izračune vidjeti u Ježovita, 2018, 81-83).

Tablica 5: Prosječne vrijednosti izabranih pokazatelja učinkovitosti djelovanja proračunskih korisnika u Republici Hrvatskoj (2012.-2017.)

\begin{tabular}{|c|r|r|r|r|}
\hline Godina & $\begin{array}{r}\text { Ekonomičnost } \\
\text { poslovanja }\end{array}$ & $\begin{array}{r}\text { Ekonomičnost } \\
\text { upravljanja dugom }\end{array}$ & Stopa viška/manjka & $\begin{array}{r}\text { Omjer obračunatih i } \\
\text { naplaćenih prihoda }\end{array}$ \\
\hline 2012 & 1,1495 & 0,7871 & $-0,0092$ & 0,3165 \\
\hline 2013 & 1,1712 & 0,8001 & $-0,0049$ & 0,3105 \\
\hline 2014 & 1,1967 & 1,1533 & $-0,0087$ & 0,2278 \\
\hline 2015 & 1,1436 & 1,7838 & 0,0083 & 0,5491 \\
\hline 2016 & 1,1839 & 2,9680 & 0,0138 & 0,2490 \\
\hline 2017 & 1,1162 & 1,2757 & 0,0314 & 0,3385 \\
\hline
\end{tabular}

Izvor: Izračun autora

Prosječna vrijednost ekonomičnosti poslovanja i ekonomičnosti upravljanja dugom promatrano prema analiziranim godinama nema pravilan trend kretanja (Tablica 5). Štoviše, pokazatelj ekonomičnosti poslovanja ima najlošiju vrijednost u 2017. godini u odnosu na ostala promatrana razdoblja, odnosno tijekom 2017. godine analizirani proračunski korisnici imali su u prosjeku $11,62 \%$ veće prihode poslovanja od rashoda poslovanja, tj. 11,62\% prihoda poslovanja imali su na raspolaganju za pokrivanje rashoda za nabavu nefinancijske imovine i izdataka za financijsku imovinu i otplatu zajmova. S druge strane, ekonomičnost upravljanja dugom sve do 2016. godine ima trend povećanja dok je 2017. godine vrijednost pokazatelja više od dvostruko niža, što je pozitivna naznaka. Prema navedenom pokazatelju 2017. godine proračunski korisnici se u prosjeku 1,28 puta više zadužuju nego što otplaćuju glavnice primljenih kredita i zajmova. Sposobnost proračunskih korisnika da zadržava određeni dio prihoda i primitaka nakon pokrivanja svih rashoda i izdataka te se stoga može smatrati izravnim pokazateljem učinkovitosti. Primjetno je da analizirani proračunski korisnici u prosjeku 
povećavaju svoju učinkovitost kroz promatrane godine, od neučinkovitog djelovanja u 2012., 2013. i 2014. godini do sve bolje učinkovitosti do 2017. godine kada je jedna jedinica u prosjeku imala $3,14 \%$ veće prihode i primitke od rashoda i izdataka. Kao i kod ekonomičnosti upravljanja dugom, omjer obračunatih i naplaćenih prihoda trebao bi biti što manji. Analizirani podaci po godinama ne ukazuju na određeni trend, a u 2017. godini analizirana jedinica je u prosjeku imala $33,85 \%$ obračunatih prihoda u ukupno naplaćenih prihoda te godine. Unatoč većem omjeru obračunatih i naplaćenih prihoda, kao i činjenice da je ekonomičnost upravljanja dugom veća od 1, može se zaključiti da su analizirani proračunski korisnici u 2017. godini bili djelotvorni s obzirom da povoljne rezultate ekonomičnosti poslovanja i ostvarivanja viška prihoda i primitaka koji bi trebali predstavljati svojevrsnu polugu daljnjeg rasta i razvoja (Ježovita, 2018, 84).

Tablica 6: Deskriptivna statistika izabranih pokazatelja ekonomičnosti proračunskih korisnika prema razini ustrojstva u Republici Hrvatskoj (2012.-2017.)

\begin{tabular}{|l|c|c|c|c|c|c|}
\hline & \multicolumn{3}{|c|}{ Ekonomičnost poslovanja } & \multicolumn{3}{c|}{ Ekonomičnost upravljanja dugom } \\
\cline { 2 - 7 } & AS & Min & Max & AS & Min & Max \\
\hline Lokalna razina & 1,1732 & 0,7343 & 1,7270 & 2,0037 & 0,0000 & 55,2916 \\
\hline Regionalna i lokalna razina & 1,0813 & 0,9995 & 1,1983 & 1,8217 & 0,8061 & 5,3976 \\
\hline Regionalna razina & 1,1307 & 0,7708 & 1,5644 & 0,4967 & 0,0000 & 10,6299 \\
\hline Središnja razina & 1,1692 & 0,7421 & 4,6695 & 0,7425 & 0,0000 & 12,9447 \\
\hline
\end{tabular}

Legenda: AS - aritmetička sredina; Min - minimalna vrijednost; Max maksimalna vrijednost

Izvor: Izračun autora

Promatrano prema razinama ustrojstva u 2017. godini, primjetne su razlike u prosječnim vrijednostima prethodno analiziranih pokazatelja (Tablica 6). Najbolju ekonomičnost poslovanja imaju jedinice lokalne samouprave sa $17,32 \%$ većih prihoda poslovanja od rashoda poslovanja, a najmanju Grad Zagreb s 8,13\%. Istovremeno, jedinice lokalne samouprave imaju najnepovoljniju vrijednost ekonomičnosti upravljanja dugom što znači da su tekućeg razdoblja imali dvostruko više primitaka od zaduživanja od izdataka za otplatu glavnice primljenih kredita i zajmova. Međutim, važno je znati da visoka vrijednost toga pokazatelja ne mora nužno značiti neučinkovito poslovanje. Pokazatelj je potrebno promatrati zajedno sa stupnjem obnove proizvedene dugotrajne imovine kako bi se došlo do zaključka je li novo zaduženje na ime dugoročnih ulaganja u nefinancijsku imovinu ili se radi o nekom drugom aspektu zaduživanja, primjerice na ime redovnog izvršenja rashoda poslovanja. U ovom slučaju prosječna vrijednost stupnja obnove proizvedene dugotrajne imovine jedinica lokalne samouprave je 3,89\% što se može smatrati izrazito nisko. Indikativno je da jedinice lokalne samouprave imaju manjak prihoda i primitaka za 3,5\% što znači da imaju značajan manjak ili na ime rashoda za nabavu nefinancijske imovine ili na ime izdataka za financijsku imovinu i otplatu zajmova. U analiziranom uzorku u većoj je mjeri razlog većih rashoda za nabavu nefinancijske imovine. $\mathrm{Na}$ lokalnoj razini najmanju ekonomičnost poslovanja ima Grad Virovitica u 2016. godini, što je ujedno 
najlošiji ukupni rezultat, a najveću Grad Makarska u 2012. godini. Na regionalnoj razini najlošiju vrijednost pokazatelja ima Ličko-senjska županija za 2016. godinu, a najpovoljniju Virovitičko-podravska županija. Kod tijela državne uprave najlošiji rezultat imalo je Ministarstvo regionalnoga razvoja i fondova Europske unije u 2017. godini, a najbolji Ministarstvo gospodarstva, poduzetništva i obrta u 2016. godini, što je ukupno najbolja ekonomičnost poslovanja.

Tablica 7: Deskriptivna statistika izabranih pokazatelja svrhovitosti proračunskih korisnika prema razini ustrojstva u Republici Hrvatskoj (2012.-2017.)

\begin{tabular}{|l|c|c|c|c|c|c|}
\hline & \multicolumn{3}{|c|}{ Stopa viška/manjka } & \multicolumn{2}{c|}{ Omjer obračunatih i naplaćenih prihoda } \\
\hline & AS & Min & Max & AS & Min & Max \\
\hline Lokalna razina & $-0,0350$ & $-0,6904$ & 0,4320 & 0,2879 & 0,0000 & 0,9885 \\
\hline Regionalna i lokalna razina & $-0,0418$ & $-0,1153$ & $-0,0042$ & 0,2192 & 0,1821 & 0,3195 \\
\hline Regionalna razina & 0,0254 & $-0,1871$ & 0,3728 & 0,0558 & 0,0000 & 0,4636 \\
\hline Središnja razina & 0,0453 & $-0,1413$ & 0,9386 & 0,6147 & 0,0000 & 28,2295 \\
\hline
\end{tabular}

Legenda: $A S$ - aritmetička sredina; Min - minimalna vrijednost; Max maksimalna vrijednost

Izvor: Izračun autora

Najbolju stupu viška prihoda i primitaka imaju tijela državne uprave (4,53\%), kod kojih je ujedno ostvaren ukupno najpovoljniji rezultat u 2012. godini od strane Ministarstva gospodarstva (Tablica 7). S druge strane, u Međimurskoj županiji za 2012. godinu ostvarena je najviša stopa manjka prihoda i primitaka $(-37,28 \%)$. Istovremeno Međimurska županija ima najveći udio obračunatih u naplaćenim prihodima za 2017. godinu (46,36\%). Prosječno promatrano najmanji udio obračunatih u naplaćenim prihodima $u$ prosjeku imaju jedinice regionalne samouprave, a najveći, u prosjeku čak $61,47 \%$, tijela državne uprave gdje je Ministarstvo financija u 2015. godini imalo više od 28 puta veće obračunate prihode od naplaćenih. Takav nepovoljan rezultat se nije odrazio i na ekonomičnost poslovanja gdje su u toj istoj godini ostvarili $7,25 \%$ više prihoda i od rashoda poslovanja, ali se odrazilo na ukupni rezultat gdje su imali 4,49\% manjka prihoda i primitaka.

Tablica 8: Prosječne vrijednosti izabranih pokazatelja kapitalnih investicija proračunskih korisnika u Republici Hrvatskoj (2012.-2017.)

\begin{tabular}{|c|c|c|}
\hline Godina & $\begin{array}{c}\text { Stupanj obnove proizvedene dugotrajne } \\
\text { imovine }\end{array}$ & $\begin{array}{c}\text { Investiranje u novu dugotrajnu } \\
\text { nefinancijsku imovinu }\end{array}$ \\
\hline 2012 & 0,4064 & 0,0745 \\
\hline 2013 & 0,3368 & 0,0661 \\
\hline 2014 & 0,2792 & 0,0594 \\
\hline 2015 & 0,1673 & 0,0676 \\
\hline 2016 & 0,1149 & 0,0647 \\
\hline 2017 & 0,0893 & 0,0542 \\
\hline
\end{tabular}

Izvor: Izračun autora 
Stupanj obnove mjeri godišnju razinu ulaganja u proizvedenu dugotrajnu imovinu, a pokazateljem investiranja u novu dugotrajnu nefinancijsku imovinu mjere se ulaganja u fazi izgradnje i pripreme za korištenje. Radi se o pokazateljima kojima se može ocijeniti stvaranje pretpostavki za uspješno buduće djelovanje. Od 2012. do 2016. godine primjetan je kontinuirani trend smanjenja ulaganja u proizvedenu dugotrajnu imovinu od 40,64\% u 2012. godini do 8,93\% u 2017. godini (Tablica 8). To znači da proračunski korisnici u prosjeku imaju sve manje rashoda za nabavu proizvedene dugotrajne imovine u ukupnoj proizvedenoj dugotrajnoj imovini. S druge strane, stopa investiranja u novu dugotrajnu nefinancijsku imovinu otprilike je na istoj razini kroz šestogodišnje razdoblje, tj. u 2017. godini proračunski korisnici u prosjeku imaju 5,42\% dugotrajne nefinancijske imovine u pripremi u ukupnoj imovini.

Tablica 9: Deskriptivna statistika izabranih pokazatelja kapitalnih investicija proračunskih korisnika prema razini ustrojstva u Republici Hrvatskoj (2012.-2017.)

\begin{tabular}{|l|c|c|c|c|c|c|}
\hline & \multicolumn{3}{|c|}{$\begin{array}{c}\text { Stupanj obnove proizvedene } \\
\text { dugotrajne imovine }\end{array}$} & \multicolumn{3}{c|}{$\begin{array}{c}\text { Investiranje u novu dugotrajnu } \\
\text { nefinancijsku imovinu }\end{array}$} \\
\hline & AS & Min & Max & AS & Min & Max \\
\hline Lokalna razina & 0,0389 & 0,0025 & 0,2045 & 0,04 & 0,00 & 0,30 \\
\hline $\begin{array}{l}\text { Regionalna i lokalna } \\
\text { razina }\end{array}$ & 0,1983 & 0,0616 & 0,4461 & 0,37 & 0,35 & 0,38 \\
\hline Regionalna razina & 0,5472 & 0,0036 & 3,4967 & 0,10 & 0,00 & 0,66 \\
\hline Središnja razina & 0,2419 & 0,0000 & 5,2294 & 0,06 & 0,00 & 0,75 \\
\hline
\end{tabular}

Legenda: AS - aritmetička sredina; Min - minimalna vrijednost; Max maksimalna vrijednost

Izvor: Izračun autora

Promatrano prema razini ustrojstva (Tablica 9), jedinice regionalne (područne) samouprave u prosjeku imaju najveća ulaganja u proizvedenu dugotrajnu imovinu (54,72\%), a jedinice lokalne samouprave najmanja (3,89\%). Grad Zagreb u prosjeku ima najveći udio dugotrajne nefinancijske imovine u pripremi (37\%). Može se zaključiti da gradovi imaju najmanja ulaganja u nefinancijsku dugotrajnu imovinu. S druge strane, kada su u pitanju županije moglo bi se zaključiti da se radi o ulaganjima temeljem kojih je imovina stavljena u upotrebu u roku do godine dana, za razliku od Grada Zagreba gdje se radi o višegodišnjim projektima s obzirom na visoki udio imovine u pripremi. 
Tablica 10: Prosječne vrijednosti izabranih pokazatelja financijskog stanja proračunskih korisnika u Republici Hrvatskoj (2012.-2017.)

\begin{tabular}{|c|r|r|r|r|r|r|}
\hline Godina & $\begin{array}{c}\text { Sposobnost } \\
\text { plaćanja } \\
\text { dospjelih } \\
\text { obveza }\end{array}$ & $\begin{array}{c}\text { Koeficijent } \\
\text { tekuće } \\
\text { likvidnosti }\end{array}$ & $\begin{array}{c}\text { Koeficijent } \\
\text { financijske } \\
\text { stabilnosti }\end{array}$ & $\begin{array}{c}\text { Koeficijent } \\
\text { zaduženosti }\end{array}$ & $\begin{array}{c}\text { Relativna } \\
\text { naknada na } \\
\text { dospjelu } \\
\text { glavnicu }\end{array}$ & $\begin{array}{c}\text { Stupanj } \\
\text { povećanja } \\
\text { zaduženosti }\end{array}$ \\
\hline 2012 & & 19,3465 & 0,6643 & 0,2328 & 0,2433 & 0,2032 \\
\hline 2013 & 41,7726 & 19,8727 & 0,7454 & 0,1873 & 0,2077 & 0,5361 \\
\hline 2014 & 76,2992 & 22,1310 & 0,7194 & 0,1768 & 0,2141 & 0,1398 \\
\hline 2015 & 2,9637 & 23,8472 & 0,7114 & 0,1574 & 0,1944 & 0,1710 \\
\hline 2016 & 0,7887 & 53,3951 & 0,7038 & 0,1653 & 0,2466 & 0,9909 \\
\hline 2017 & 79,8275 & 45,8955 & 0,7059 & 0,1540 & 0,2576 & 0,2747 \\
\hline
\end{tabular}

\section{Izvor: Izračun autora}

Prema pokazatelju sposobnost plaćanja dospjelih obveza analizirani proračunski korisnici u prosjeku su svih godina, osim 2016. godine, višestruku mogli podmiriti dospjele obveze novcem na računu i u blagajni na dan sastavljanja bilance (Tablica 10). Koeficijent tekuće likvidnosti koji se izračunava kao omjer financijske imovine i obveza za rashode poslovanja također je povoljan u svim promatranim godinama. Razlog tome je mali udio obveza u strukturi izvora imovine što potvrđuje koeficijent zaduženosti koji ukazuje na smanjenje statičke zaduženosti u razdoblju od 2012. do 2017. godine. Analizirani proračunski korisnici su 2017. godine u prosjeku $15,40 \%$ ukupne imovine financirali iz tuđih izvora financiranja. Prema dobivenim rezultatima, u 2017. godini rashodi od kamata čine 25,76\% izdataka za otplatu glavnice primljenih kredita i zajmova. Također, moguće je primijetiti povećanje zaduživanja na godišnjoj razini u prosjeku za 27,47\% u 2017. godini, a s obzirom na smanjivanje statičke zaduženosti, te da se prosječne vrijednosti ukupne imovine i obveza nisu značajno mijenjale, zaključak je da se radi o kratkoročnom zaduživanju. Prema koeficijentu financijske stabilnosti, proračunski korisnici u prosjeku više od $70 \%$ dugoročnih izvora koriste za financiranje nefinancijske imovine, a preostalih $30 \%$ za financiranje financijske imovine.

Tablica 11:Deskriptivna statistika izabranih pokazatelja likvidnosti proračunskih korisnika prema razini ustrojstva u Republici Hrvatskoj (2012.-2017.)

\begin{tabular}{|l|c|c|c|c|c|c|c|c|c|}
\hline & \multicolumn{3}{|c|}{$\begin{array}{c}\text { Sposobnost plaćanja } \\
\text { dospjelih obveza }\end{array}$} & \multicolumn{3}{c|}{$\begin{array}{c}\text { Koeficijent tekuće } \\
\text { likvidnosti }\end{array}$} & \multicolumn{3}{c|}{$\begin{array}{c}\text { Koeficijent financijske } \\
\text { stabilnosti }\end{array}$} \\
\hline & AS & Min & Max & AS & Min & Max & AS & Min & Max \\
\hline Lokalna razina & 29,19 & 0,00 & 556,95 & 17,73 & 1,40 & 84,18 & 0,81 & 0,46 & 0,99 \\
\hline $\begin{array}{l}\text { Regionalna i } \\
\text { lokalna razina }\end{array}$ & 2,24 & 0,44 & 3,51 & 12,31 & 5,96 & 17,55 & 0,65 & 0,60 & 0,69 \\
\hline $\begin{array}{l}\text { Regionalna } \\
\text { razina }\end{array}$ & 119,84 & 0,01 & 2103,23 & 8,01 & 0,40 & 50,21 & 0,56 & 0,04 & 1,12 \\
\hline Središnja razina & 105,25 & 0,00 & 910,09 & 67,46 & 0,15 & 2709,73 & 0,70 & $-6,24$ & 3,22 \\
\hline
\end{tabular}

Legenda: $A S$ - aritmetička sredina; Min - minimalna vrijednost; Maxmaksimalna vrijednost

Izvor: Izračun autora 
Tijekom šestogodišnjeg razdoblja Grad Zagreb u prosjeku 2,25 puta može dospjele obveze podmiriti novcem na računu i u blagajni, dok županije raspolažu s najviše novca na dan sastavljanja bilance u odnosu na dospjele obveze (Tablica 11). S druge strane, županije imaju najlošiji koeficijent tekuće likvidnosti te financijskom imovinom mogu 8 puta pokriti obveze. Uvažavajući i koeficijent financijske stabilnosti, ukupno promatrano tijela državne uprave (središnja razina) imaju najpovoljniju likvidnost.

Tablica 12: Deskriptivna statistika izabranih pokazatelja zaduženosti proračunskih korisnika prema razini ustrojstva u Republici Hrvatskoj (2012.-2017.)

\begin{tabular}{|l|c|c|c|c|c|c|c|c|c|}
\hline & \multicolumn{2}{|c|}{ Koeficijent zaduženosti } & \multicolumn{3}{c|}{$\begin{array}{c}\text { Relativna naknada na } \\
\text { dospjelu glavnicu }\end{array}$} & \multicolumn{3}{c|}{$\begin{array}{c}\text { Stupanj povećanja } \\
\text { zaduženosti }\end{array}$} \\
\hline & AS & Min & Max & AS & Min & Max & AS & Min & Max \\
\hline Lokalna razina & 0,0517 & 0,0037 & 0,2759 & 0,2303 & 0,0000 & 4,2086 & 0,4361 & 0,0000 & 41,7400 \\
\hline $\begin{array}{l}\text { Regionalna i } \\
\text { lokalna razina }\end{array}$ & 0,1109 & 0,0697 & 0,1302 & 0,2962 & 0,1946 & 0,4098 & 0,3339 & 0,1334 & 0,7957 \\
\hline $\begin{array}{l}\text { Regionalna } \\
\text { razina }\end{array}$ & 0,2641 & 0,0111 & 0,6652 & 0,2696 & 0,0000 & 3,8690 & 0,1412 & 0,0000 & 1,0000 \\
\hline $\begin{array}{l}\text { Središnja } \\
\text { razina }\end{array}$ & 0,2853 & 0,0004 & 3,6262 & 0,0897 & 0,0000 & 0,4429 & 0,6452 & 0,0000 & 20,3637 \\
\hline
\end{tabular}

Legenda: AS - aritmetička sredina; Min - minimalna vrijednost; Max maksimalna vrijednost

Izvor: Izračun autora

Iako imaju u prosjeku najveću statičku zaduženost kao i stupanj povećanja zaduženosti, tijela državne uprave ostvaruju najmanju relativnu naknadu na dospjelu glavnicu pa se mogu smatrati i najmanje zaduženima (Tablica 12). S druge strane, gradovi (uključujući i Grad Zagreb) iako imaju najmanju statičku zaduženost, imaju najvišu relativnu naknadu na dospjelu glavnicu što može biti posljedica skupljeg kratkoročnog zaduživanja. Ukupno promatrano jedinice središnje razine u prosjeku imaju najpovoljnije financijsko stanje, a gradovi najnepovoljnije.

Uspoređujući učinkovitost i financijsko stanje analiziranih jedinica prema razinama ustrojstva moguće je primijetiti određene razlike s financijskog aspekta. Međutim, postavlja se pitanje jesu li te razlike i statistički značajne. U tom kontekstu oblikovana je prva istraživačka hipoteza:Postoje statistički značajne razlike $u$ učinkovitosti $i$ financijskom stanju između jedinica na različitim razinama ustrojstva u Republici Hrvatskoj. S obzirom da podaci nisu normalno distribuirani te postoje ekstremne vrijednosti u distribuciji, testiranje je provedeno primjenom neparametarskogKruskal-Wallis testa koji se temelji na medijanima umjesto na aritmetičkoj sredini kao analiza varijanci. 
Tablica 13: Rezultati neparametarskogKruskal-Wallis testa za odabrane financijske pokazatelje proračunskih korisnika klasificiranih prema razinama ustrojstva u

Republici Hrvatskoj u 2017. godini

\begin{tabular}{|l|r|r|r|}
\hline & $\begin{array}{r}\text { Kruskal- } \\
\text { Wallis H }\end{array}$ & df & $\begin{array}{r}\text { Asymp. } \\
\text { Sig. }\end{array}$ \\
\hline Ekonomičnost poslovanja & 61,263 & 3 & 0,000 \\
\hline Ekonomičnost upravljanja dugom & 21,267 & 3 & 0,000 \\
\hline Stopa viška/manjka & 27,239 & 3 & 0,000 \\
\hline Omjer obračunatih i naplaćenih prihoda & 197,991 & 3 & 0,000 \\
\hline Stupanj obnove proizvedene dugotrajne imovine & 120,247 & 3 & 0,000 \\
\hline Investiranje u novu dugotrajnu nefinancijsku imovinu & 44,591 & 3 & 0,000 \\
\hline Sposobnost plaćanja dospjelih obveza & 3,138 & 3 & 0,371 \\
\hline Koeficijent tekuće likvidnosti & 139,067 & 3 & 0,000 \\
\hline Koeficijent financijske stabilnosti & 59,077 & 3 & 0,000 \\
\hline Koeficijent zaduženosti & 138,168 & 3 & 0,000 \\
\hline Relativna naknada na dospjelu glavnicu & 29,885 & 3 & 0,000 \\
\hline Stupanj povećanja zaduženosti & 14,881 & 3 & 0,002 \\
\hline
\end{tabular}

Izvor: Izračun autora

Za sve izabrane pokazatelje, osim sposobnosti plaćanja dospjelih obveza, empirijska razina signifikantnosti je ,000 i manja je o teorijske razine od ,050 te se uslijed toga za te varijable ne može prihvatiti nulta statistička hipoteza da je distribucija testiranih pokazatelja jednaka među različitim razinama ustrojstva proračunskih korisnika (Tablica 13). Prema tome, može se zaključiti da je distribucija podataka za gotovo sve analizirane pokazatelje različita u odnosu na razinu upravljanja čime se prihvaća prva istraživačka hipoteza da postoje statistički značajne razlike u učinkovitosti i financijskom stanju između jedinica na različitim razinama ustrojstva u Republici Hrvatskoj.

Uslijed tako dobivenih rezultata, opravdano se postavlja pitanje postoji li povezanost financijskog djelovanja proračunskih korisnika sa stupnjem razvoja područja kojim taj proračunski korisnik upravlja prema čemu druga istraživačka hipoteza glasi: Razvijenost pojedinog geografskog područja uvjetovana je djelotvornošću upravljanja raspoloživim prihodima toga područja.

Stupanj razvoja pojedine jedinice lokalne i regionalne (područne) samouprave može se mjeriti indeksom razvijenosti Ministarstva regionalnog razvoja i fondova Europske unije koje je razvijen kao pokazatelj za utvrđivanje potpomognutih područja Republike Hrvatske 2017. godine i njegov izračun uređen je Uredbom o indeksu razvijenosti (Narodne novine broj 131/2017). Za potrebe analize povezanosti djelotvornosti proračunskog korisnika i njegovog područja djelovanja korišten je indeks razvijenosti izračunat za razdoblje 2014.-2016. godine. 
Tablica 14: Deskriptivna statistika indeksa razvijenosti prema razinama u Republici Hrvatskoj (2014.-2016.)

\begin{tabular}{|l|c|c|c|c|c|}
\hline Indeks razvijenosti & $\begin{array}{c}\text { Aritmetička } \\
\text { sredina }\end{array}$ & $\begin{array}{c}\text { Standardna } \\
\text { devijacija }\end{array}$ & Medijan & Minimum & Maksimum \\
\hline Lokalna razina & 107.32 & 4.04 & 107.81 & 98.69 & 115.64 \\
\hline $\begin{array}{l}\text { Regionalna i lokalna } \\
\text { razina }\end{array}$ & 117.76 & - & 117.76 & 117.76 & 117.76 \\
\hline Regionalna razina & 98.60 & 5.99 & 97.77 & 90.67 & 108.97 \\
\hline Središnja razina & 105.50 & - & 105.50 & 105.50 & 105.50 \\
\hline
\end{tabular}

Izvor: Obrada autora prema podacima dostupnima na Internet stranici

Ministarstva regionalnog razvoja i fondova Europske unije

Očekivano, najviši indeks razvijenosti u Republici Hrvatskoj ima Grad Zagreb $(117,76)$. Za razliku od prethodnih rezultata, gdje su se jedinice središnje razine pokazale najvećima, ovdje su na trećem mjestu (Tablica 14). Važno je istaknuti da je svim jedinicama središnje razine dodijeljen indeks razvijenosti koji se odnosi na cijelu državu, a koji je izračunat kao ponderirani prosjek indeksa razvijenosti jedinica lokalne samouprave (gradova i općina) (Ministarstvo regionalnog razvoja i fondova Europske unije, web). Kao ponder korišten je broj stanovnika jedinica lokalne samouprave temeljem popisa iz 2011. godine (Državni zavod za statistiku, web). Kao i u slučaju prethodnih rezultata, najmanje razvijene su jedinice regionalne (područne) samouprave $(98,60)$. Prema pokazatelju najrazvijenija je, izuzev Grada Zagreba, Istarska županija $(108,97)$, zatim Dubrovačko-neretvanska županija $(108,58)$, a najmanje razvijena Virovitičko-podravska županija $(90,67)$. U pogledu gradova, nakon Grada Zagreba, najrazvijeniji je grad Dubrovnik $(115,64)$, zatim Grad Poreč $(114,00)$, a najmanje razvijen je grad Petrinja $(98,69)$.

Radi utvrđivanja djelotvornosti jedinica lokalne i regionalne (područne) samouprave kao i jedinica na središnjoj razini i usporedbe s rezultatima dobivenih financijskim pokazateljima korištena je izlazno-usmjerena metoda analize omeđivanja podataka uz varijabilne prinose s jednom izlaznom, prihodi poslovanja $(\mathrm{Y})$ i triulazne varijable: ukupna imovina $\left(\mathrm{x}_{1}\right)$, obveza $\left(\mathrm{x}_{2}\right)$ i ukupni rashodi i izdaci $\left(\mathrm{x}_{3}\right)$. Izlazno-usmjerenom analizom omeđivanja podataka bavi se pitanjem koliko se mogu proporcionalno smanjiti količine inputa bez mijenjanja proizvedeno količine outputa, odnosno u ovoj primjeni koliko se mogu smanjiti imovina, obveze ili ukupni rashodi i izdaci bez promjene prihoda poslovanja. Zapravo se želi istražiti koliko djelotvorno jedinice raspolažu s prihodima poslovanja. Izračuni su dobiveni softwareskim rješenjem DEAP 2.1. 
Tablica 15: Klasifikacija rezultata analize omeđivanja podataka prema skupinama djelotvornosti analiziranih proračunskih korisnika

\begin{tabular}{|l|c|c|c|c|}
\hline \multicolumn{1}{|c|}{ Rang djelotvornosti } & $\begin{array}{c}\text { Broj } \\
\text { jedinica }\end{array}$ & $\begin{array}{c}\text { Udio jedinica prema } \\
\text { rangu djelotvornosti }\end{array}$ & $\begin{array}{c}\text { Tehnička } \\
\text { djelotvornost }\end{array}$ & $\begin{array}{c}\text { Djelotvornost } \\
\text { razmjera }\end{array}$ \\
\hline Djelotvorno (1,000) & 12 & $15 \%$ & 0.99 & 1.00 \\
\hline $\begin{array}{l}\text { Uvjetna djelotvornost (0,642- } \\
\text { 0,869 s djelotvornosti } \\
\text { razmjera 1,000) }\end{array}$ & 13 & $16 \%$ & 0.79 & 1.00 \\
\hline $\begin{array}{l}\text { Nedjelotvorno (0,538-0,999 s } \\
\text { djelotvornosti razmjera } \\
<1,000)\end{array}$ & 44 & $54 \%$ & 0.76 & 0.98 \\
\hline $\begin{array}{l}\text { Izrazito nedjelotvorno (0,700- } \\
\text { 0,800) }\end{array}$ & 9 & $11 \%$ & 0.76 & 0.91 \\
\hline $\begin{array}{l}\text { Najveća nedjelotvornost } \\
(<0,700)\end{array}$ & 3 & $4 \%$ & 0.68 & 0.96 \\
\hline
\end{tabular}

Izvor: Izračun autora

Tehnička djelotvornost (engl. techincalefficiency) označava sposobnost poduzeća da stvori maksimalni output $\mathrm{s}$ zadanim setom inputa, a djelotvornost razmjera (engl. scaleefficiency) predstavlja zajedničku mjeru tehničke i alokativne djelotvornosti koja označava sposobnost poduzeća da koristi inpute u optimalnim proporcijama, uvažavajući njihove cijene (Coelli, 1996).Prema dobivenim rezultatima analize omeđivanja podataka 12 analiziranih jedinica smatra se djelotvornima, a sve su dio središnje razine upravljanja i pretežno se odnose na djelovanje ministarstva (Tablica 15). Sve ostale jedinice smatraju se nedjelotvornima koje su radi velikog udjela podijeljene prema stupnju nedjelotvornosti. U skupini uvjetne djelotvornosti nalaze se one jedinice koje imaju tehničku djelotvornost manju od 1, ali im je djelotvornost razmjera jednaka 1,000. U toj skupini najlošiji pokazatelj ima Grad Šibenik $(0,642)$, a najbolji u vrijednosti 0,869 imaju Državni zavod za statistiku i Splitsko-dalmatinska županija. Najveći dio analiziranih jedinica smatra se neefikasnima, s rasponom tehničke djelotvornosti 0,538-0,999 i djelotvornosti razmjera manjom od 1,000. U toj skupni nalazi se većina gradova, više od polovice županija i 10 ministarstava. Grad Zagreb se također smatra nedjelotvornim s tehničkom djelotvornosti 0,904 i djelotvornosti razmjera 0,71. Najlošiji rezultat u skupini ima Grad Opatija (TE 0,538, SE 0,997), a najbolji Ministarstvo unutarnjih poslova (TE 0,994; SE 0,804). Izrazito nedjelotvornima se smatra $11 \%$ analiziranih jedinica. Radi se o skupini koja ima tehničku djelotvornost manju od 0,800 kao i djelotvornost razmjera manju od 1,000 te imaju opadajući povrat na razmjer. U toj skupini nalaze se gradovi koji se smatraju razvijenima s gospodarskog aspekta, kao što su npr. grad Dubrovnik $(0,753)$ ili grad Varaždin $(0,736)$. Najlošije je ocjenjeno $4 \%$ analiziranih jedinica koje uz djelotvornost razmjera manju od 1,000 i opadajući povrat na razmjer imaju tehničku djelotvornost manju od 0,700.Najlošije je ocijenjena, po makroekonomskim indikatorima izrazito uspješna, Istarska županija $(0,674)$. 
Tablica 16: Prosječne vrijednosti (2014.-2016.) odabranih stavki iz financijskih izvještaja proračunskih korisnika u odnosu na rang djelotvornosti

\begin{tabular}{|l|r|r|r|r|}
\hline \multicolumn{1}{|c|}{ Rang djelotvornosti } & \multicolumn{1}{c|}{$\begin{array}{c}\text { Ukupna } \\
\text { imovina }\end{array}$} & \multicolumn{1}{c|}{ Obveze } & \multicolumn{1}{c|}{$\begin{array}{c}\text { Prihodi } \\
\text { poslovanja }\end{array}$} & \multicolumn{1}{c|}{$\begin{array}{c}\text { Ukupno rashodi i } \\
\text { izdaci }\end{array}$} \\
\hline Djelotvorno & \multicolumn{1}{|c|}{449.631 .160} & 190.606 .755 & 2.015 .016 .336 & 2.001 .251 .144 \\
\hline Uvjetna djelotvornost & 791.122 .011 & 31.724 .212 & 197.783 .458 & 203.019 .955 \\
\hline Nedjelotvorno & 4.247 .124 .184 & 137.229 .136 & 507.926 .134 & 528.059 .207 \\
\hline Izrazito nedjelotvorno & 4.059 .808 .270 & 178.955 .516 & 391.889 .860 & 412.264 .163 \\
\hline $\begin{array}{l}\text { Najveća } \\
\text { nedjelotvornost }\end{array}$ & 1.097 .553 .551 & 71.923 .331 & 238.823 .078 & 262.171 .801 \\
\hline
\end{tabular}

\section{Izvor: Izračun autora}

Zanimljivo je da najbolju djelotvornost upravljanja imaju jedinice s prosječno najvećim iznosima prihoda poslovanja i ukupnim rashodima i izdacima dok s druge strane te jedine u prosjeku imaju najmanju vrijednost imovine.

Tablica 17: Prosječne vrijednosti izabranih financijskih pokazatelja (2014.-2016.) u odnosu na rang djelotvornosti analiziranih proračunskih korisnika i rezultati

neparametarskog testa

\begin{tabular}{|c|c|c|c|c|c|c|}
\hline $\begin{array}{l}\text { Rang } \\
\text { djelotvornost } \\
\text { i }\end{array}$ & $\begin{array}{l}\text { Djelotvorn } \\
\mathrm{o}\end{array}$ & $\begin{array}{l}\text { Uvjetna } \\
\text { djelotvorno } \\
\text { st }\end{array}$ & $\begin{array}{l}\text { Nedjelotvorn } \\
\mathrm{o}\end{array}$ & $\begin{array}{l}\text { Izrazito } \\
\text { nedjelotvorn } \\
\text { o }\end{array}$ & $\begin{array}{l}\text { Najveća } \\
\text { nedjelotvorno } \\
\text { st }\end{array}$ & $\begin{array}{c}\text { Kruskal- } \\
\text { Walls Test p- } \\
\text { value(razlika } \\
\text { u } \\
\text { djelotvornosti } \\
\text { ) }\end{array}$ \\
\hline $\begin{array}{l}\text { Tehnička } \\
\text { djelotvornost }\end{array}$ & 0,99 & 0,79 & 0,76 & 0,76 & 0,68 & ,000 \\
\hline $\begin{array}{l}\text { Ekonomično } \\
\text { st ukupnog } \\
\text { djelovanja }\end{array}$ & 1,06 & 0,99 & 1,02 & 1,01 & 1 & ,132 \\
\hline $\begin{array}{l}\text { Kvaliteta } \\
\text { prihoda }\end{array}$ & 1 & 0,98 & 0,95 & 0,95 & 0,91 & ,000 \\
\hline $\begin{array}{l}\text { Koeficijent } \\
\text { trenutne } \\
\text { likvidnosti }\end{array}$ & 0,08 & 0,94 & 1,26 & 1,51 & 1,61 & 0,003 \\
\hline $\begin{array}{l}\text { Koeficijent } \\
\text { obrta } \\
\text { financijske } \\
\text { imovine }\end{array}$ & 36,44 & 4,22 & 4,35 & 0,91 & 1,11 & 0,000 \\
\hline $\begin{array}{l}\text { Koeficijent } \\
\text { zaduženosti }\end{array}$ & 0,4 & 0,22 & 0,11 & 0,07 & 0,1 & 0,150 \\
\hline $\begin{array}{l}\text { Indeks } \\
\text { razvijenosti }\end{array}$ & 105,5 & 102,33 & 104,39 & 107,71 & 107,64 & 0,033 \\
\hline
\end{tabular}

\section{Izvor: Izračun autora}

Poznato je da je ekonomičnost mjera djelotvornosti pa se u tome kontekstu može zaključiti da jedinice koje su djelotvorne prema pokazatelju koji je rezultat analize omeđivanja podataka podudara s pokazateljima ekonomičnosti i kvalitete prihoda, dok s druge strane pokazatelje kojima se ocjenjuje financijsko stanje najbolje vrijednosti pokazuju najnedjelotvornije jedinice, a najlošije nedjelotvornije 
jedinice. Prema dobivenim rezultatima može se zaključiti da je potrebno ocjenjivati djelovanje proračunskih korisnika sveobuhvatno primjenom različitih financijskih pokazatelja, prije svega podijeljenih barem dvije skupine, pokazatelji djelotvornosti i pokazatelji financijskog stanja (Tablica 17). Financijsko stanje najdjelotvornijih analiziranih jedinica je na prvi pogled je najlošije, međutim premda imaju najnižu prosječnu vrijednost koeficijenta trenutne likvidnosti, izrazito visoka prosječna vrijednost koeficijenta obrta financijske imovine ukazuje na djelotvorno upravljanje imovinom. Pored toga, najdjelotvornije jedinice u prosjeku u najvećoj mjeri koriste tuđe izvore financiranja, ali s obzirom na povoljnu ekonomičnost ukupnog djelovanja i kvalitetu prihoda može se zaključiti da postoji povoljno djelovanje financijske imovine. Jedinice $s$ najvećom nedjelotvornošću imaju nepovoljnu prosječnu vrijednost financijskih pokazatelja učinkovitosti, ali povoljnu vrijednost koeficijenta trenutne likvidnosti uz nizak koeficijent obrta. Unatoč prosječno najnižem stupnju korištenja tuđih izvora, puno teže ostvaruju povoljno djelovanje financijske poluge. Također, Spearmanov koeficijent korelacije(razina signifikantnosti 1\%) pokazuje snažnu pozitivnu povezanost tehničke djelotvornosti s pokazateljima kvalitete prihoda (,709) i koeficijentom obrta financijske imovine (,657), srednje jaku pozitivnu povezanost $\mathrm{s}$ koeficijentom zaduženosti $(, 350) \mathrm{i}$ srednje jaku negativnu povezanost s koeficijentom trenutne likvidnosti $(-, 290)$. S obzirom na dobivene rezultate o postojanju razlika u distribucijama, istih zaključaka ocjenom financijskih pokazatelja učinkovitosti i pokazatelja djelotvornosti dobivenog analizom omeđivanja podataka, te detaljnijim rezultatima o učinkovitosti i financijskom stanju, zaključuje se da postoji opravdanost korištenja financijskih pokazatelja $\mathrm{u}$ analizi djelovanja proračunskih korisnika, ali se može i prihvatiti treća istraživačka hipoteza da seprimjenom financijskih pokazatelja može se preciznije odrediti financijsko stanje i učinkovitost djelovanja proračunskih korisnika nego primjenom jedinstvenog pokazatelja djelotvornosti.

Usporedbom dva provedena pristupa ocjene djelovanja proračunskih korisnika $\mathrm{s}$ indeksom razvijenosti geografskog područja na kojem djeluju pojedine analizirane jedinice dolazi se do oprečnih zaključaka, unatoč činjenici da je jedna od varijabli za izračun indeksa razvijenostiproračunski prihodi jedinica lokalne, odnosno područne (regionalne) samouprave po stanovniku.Jedinice koje su ocjenjene kao djelotvorne imaju lošiju prosječnu vrijednost indeksa razvijenosti dok najbolji indeks razvijenosti imaju najnedjelotvornije jedinice. 
Tablica 18: Prosječne vrijednosti odabranih pokazatelja i rezultati provedenog neparametarskog testiranja

\begin{tabular}{|l|c|c|c|c|}
\hline & $\begin{array}{c}\text { Tehnička } \\
\text { djelotvornost }\end{array}$ & $\begin{array}{c}\text { Ekonomičnost } \\
\text { ukupnog djelovanja }\end{array}$ & $\begin{array}{c}\text { Kvaliteta } \\
\text { prihoda }\end{array}$ & $\begin{array}{c}\text { Indeks } \\
\text { razvijenosti }\end{array}$ \\
\hline $\begin{array}{l}\text { Lokalna i regionalna } \\
\text { razina }\end{array}$ & 0.90 & 1.00 & 0.91 & 117.76 \\
\hline Lokalna samouprava & 0.70 & 1.02 & 0.92 & 107.32 \\
\hline Regionalna samouprava & 0.80 & 1.01 & 0.98 & 98.60 \\
\hline Središnja razina & 0.91 & 1.03 & 0.99 & 105.50 \\
\hline $\begin{array}{l}\text { Kruskal-Walls Test p- } \\
\text { value (razlika u razinama) }\end{array}$ &, 000 &, 802 &, 000 &, 000 \\
\hline
\end{tabular}

Izvor: Izračun autora

U odnosu na razinu upravljanja može se zaključiti da jedinice središnje razine imaju najbolje prosječne vrijednosti tehničke djelotvornosti i financijskih pokazatelja učinkovitosti (Tablica 18). S druge strane, Grad Zagreb koji u prosjeku ima najveći indeks razvijenosti ima najlošije financijske pokazatelje ekonomičnosti i svrhovitosti te imaju nepovoljnu vrijednost pokazatelja tehničke djelotvornosti. S aspekta razine upravljanja moguće je primijetiti da jedinice lokalne samouprave najlošije upravljaju raspoloživim prihodima u kontekstu raspoloživih resursa, postojećih obveza i raspodjele rashoda i izdataka. U prosjeku najbolju djelotvornost imaju jedinice središnje razine. Sveukupno promatrano, najmanju tehničku djelotvornost ima Grad Opatija $(0,538)$, a najnižu djelotvornost razmjera ima Grad Zagreb $(0,710)$. Za grad Opatiju je pozitivno što ima rastući povrat na razmjer, dok grad Zagreb ima negativni povrat na razmjer.Provedenim neparametarskim testom uz razinu signifikantnosti $5 \%$ potvrđeno je postojanje razlika u distribucijama odabranih pokazatelja u odnosu na razinu upravljanja. Kod pokazatelja ekonomičnosti ukupnog djelovanja ne može se odbaciti nulta hipoteza te se zaključuje da su distribucije na svim razinama jednake. S obzirom na rezultate da u prosjeku djelotvornije jedinice imaju manji prosječni indeks razvijenosti, i obrnuto, ne može se prihvatiti druga istraživačka hipoteza da je razvijenost pojedinog geografskog područja uvjetovana djelotvornošću upravljanja raspoloživim prihodima toga područja. Izračunati Spearmanov koeficijent korelacije (razina signifikantnosti 1\%)ukazuje na srednje jaku negativu povezanost kvalitete prihoda (-,306), koeficijenta zaduženosti $(-, 290)$, koeficijenta obrta financijske imovine (-,306) i djelotvornosti razmjera $(-, 309)$ s indeksom razvijenosti, dok s pokazateljima ekonomičnost ukupnog poslovanja i tehnička djelotvornost nema statistički značajne povezanosti.

\section{ZAKLJUČAKI RASPRAVA}

Provedenim istraživanjem došlo se do zaključka da postoje statistički značajne razlike u učinkovitosti i financijskom stanju između jedinica na različitim razinama ustrojstva u Republici Hrvatskoj, tj. jedinice na središnjoj razini imaju najbolje, a 
jedinice na lokalnoj razini najlošije financijske rezultate. Istraživanjem je utvrđeno da se primjenom financijskih pokazatelja može se preciznije odrediti financijsko stanje i učinkovitost djelovanja proračunskih korisnika nego primjenom jedinstvenog pokazatelja djelotvornosti koji je izračunat metodom analize omeđivanja podataka na temelju odabranih stavki iz financijskih izvještaja. U konačnici, najvažniji rezultat upućuje na nepostojanja povezanosti između djelotvornosti poslovanja proračunskih korisnika i razvijenosti geografskog područna na kojem taj proračunski korisnik djeluje.

Čelnici, odnosno upravljačke strukture, a prema tome i upravljanje pojedinim analiziranim jedinicama, trebalo bi imati značajnu ulogu u razvoju područja na kojem djeluju. Unatoč činjenici da je jedna od varijabli uključenih u izračun indeksa razvijenosti prihodi kojima raspolaže pojedina jedinica lokalne i regionalne (područne) samouprave, dobiveni rezultati ukazuju na značajne razlike, a pri tome se prvenstveno misli da se u najrazvijenijim jedinicama najlošije upravlja proračunskim sredstvima jedinice izravno odgovorne za to geografsko područje. Kao i u prethodnim istraživanjima, i ovim istraživanjem potvrđeno je da veći proračunski korisnici djelotvornije upravljaju raspoloživim sredstvima i resursima.

Iako se mogu isticati komparativne prednosti pojedinih područja koje privlače više stanovnika, turista, investicija, to nikako ne može biti opravdanje. Razlog razlika moguće je sagledati s aspekta metodologije izračuna indeksa razvijenosti gdje se većina uključenih varijabli odnosi na stanovništvo (stopa nezaposlenosti, dohodak po stanovniku, opće kretanje stanovništva, stope obrazovanja i indeks starenja),a samo jedna varijabla vezana je za upravljačke strukture toga područja (proračunski prihodi po stanovniku). U budućim istraživanjima moglo bi se pristupiti određivanju razvijenosti primjenom metodologije koja će uključivati odrednice kao što su primjerice izvoz, stopa inflacije, dolasci i noćenja turista, domaće i strane investicije, broj uspješnih poduzetnika i slično.

Vođenje i upravljanje proračunskog korisnika specifično je samo po sebi te se i u tome smislu mogu tražiti razlozi nedjelotvornosti, a mogu uključivati odrednice kao što je postojanje stava 'toobig to fail', a koji uobičajeno vrijedi za velike korporacije, najčešće financijske institucije, u smislu upravljanja tuđim i 'svačijim' prihodima i imovinom. Razlog može biti manjak integriteta i nepostojanja odgovornosti, tj. da jedinice ne upravljaju uvažavajući temeljna načela suvremenog upravljanja u javnom sektoru OECD-a. Značajna odrednice u smislu Republike Hrvatske može biti i česta promjena vlasti, a samim time i upravljačkih struktura u proračunskim korisnicima što zasigurno uvelike utječe na politike i strategije upravljanja proračunom. Buduća istraživanja trebala bi zasigurno uključivati i taj aspekt djelotvornosti poslovanja gdje bi se putem intervjua ili anketnih upitnika 
moglo doći do zaključaka o stavovima, vrijednostima, motivaciji čelnika i djelatnika proračunskih korisnika.

\section{LITERATURA}

1. Alibegović, J. i Blažević, Lj., (2010), Pokazatelji uspješnosti i upravljanje lokalnim razvojem: Primjer Fonda za obnovu i razvoj grada Vukovara, Ekonomski pregled, 61(11), str. 631-665.

2. Anyanwu, J. C.,(2014),FactorsAffectingEconomicGrowthinAfrica: Are ThereanyLessonsfrom China?African Development Review, 26(3), str. 468493.

3. Bađun, M., Pribičević, V.,Deskar-Škrbić, M., (2014), Government size and efficiency as constraints to economicgrowth: comparing Croatia withother European countries, Post-CommunistEconomies, 26(3), str. 297-323.

4. Bejaković, P., Vukšić, G. Bratić V., (2011.), Veličina javnog sektora u Hrvatskoj, Hrvatska i komparativna javna uprava, 11(1), str. 99-125.

5. Bogdan, Ž., (2009), Utjecaj FDI-ja na gospodarski rast europskih tranzicijskih zemalja, Serija članaka u nastajanju EFZG, Članak broj 09-06.

6. Brown, K.W., (1993), The 10-Point Test of Financial Condition: Towardan Easy-to-Use Assessment Tool for SmallerCities, Government FinanceReview, 9(6), str. 21-26.

7. Coelli, T.J., (1996), A Guide to DEAP Version 2.1: A Data Envelopment Analysis (Computer) Program, CEPA WorkingPaper 96/08, University of New England, Armidale.

8. Delić, A., Rogić Dumančić, L., (2016), Utjecaj razvijenosti financijskog sustava na gospodarski rast zemalja srednje i istočne Europe, Ekonomski pregled, 67(6), str. 535-556.

9. DjapouF., ChimeneD.,Ndedi, A. A., (2017), Analyzing Factors Affecting Economic Growth within CEMAC Countries, Available at SSRN: http://dx.doi.org/10.2139/ssrn.2986075, (datum pristupanja: 22.08.2019.)

10. Domljan, I., (2013), Mogućnosti povećanja efikasnosti usluga lokalne vodoopskrbe, doktorski rad, Sveučilište Josipa Jurja Strossmayera u Osijeku, Građevinski fakultet Osijek.

11. Državni zavod za statistiku, dostupno na: https://www.dzs.hr/Hrv_Eng /CroInFig/croinfig_2018.pdf, (datum pristupanja: 22.08.2019.)

12. Državni zavod za statistiku, Gradovi u statistici, dostupno na: www.dzs.hr, (datum pristupanja: 25.08.2019.)

13. Hrůza, F., (2015),Publicsectororganizationfinancialratios' recent development as a matteroffinancialinnovation, Investment Management and Financial Innovations, 12(2), 88-95. 
14. Jafarov, E.,Gunnarsson, V., (2008),EfficiencyofGovernmentSocialSpendingin Croatia, Financial TheoryandPractice, Institute ofPublicFinance, 32(3), str. 289-320.

15. Kablan, A., (2013.), Financial Statement Analysisin Municipalitiesandan Application. International Journal of Research in Business andSocial Science, 2(3), str. 75-86.

16. Lovre, I., Jotić, J. (2016) International ComparisonsofPublicSectorEfficiency - DEA Methodology, Industrija, Vol.44, No.2, 2016, str. 145-160

17. Međunarodna organizacija vrhovnih revizijskih institucija (INTOSAI), Međunarodni standardi vrhovnih revizijskih institucija (ISSAI), ISSAI 300 Temeljna načela revizije učinkovitosti, dostupno na: http://www.revizija.hr, (datum pristupanja: 06.08.2019.)

18. Ministarstvo financija, dostupno na: http://www.mfin.hr/hr/drzavni-proracun2017-godina, (datum pristupanja: 22.08.2019.)

19. Ministarstvo regionalnog razvoja i fondova Europske unije, Indeks razvijenosti, dostupno na: https://razvoj.gov.hr/o-ministarstvu/djelokrug1939/regionalni-razvoj/indeks-razvijenosti/vrijednosti-indeksa-razvijenosti-ipokazatelja-za-izracun-indeksa-razvijenosti-2018/3740, (datum pristupanja: 25.08.2019.)

20. Ministarstvo uprave, dostupno na: https://uprava.gov.hr/o-ministarstvu /ustrojstvo/5-uprava-za-politicki-sustav-i-organizaciju-uprave-1075/lokalna-ipodrucna-regionalna-samouprava/842, (datum pristupanja: 11.08.2019.)

21. Mustafin, A. N., Vavrek, R., (2018), Literary Review of Methods of Efficiency EvaluationinPublicSector, The Journal ofSocialSciences Research, SpecialIssue. 5, str. 170-174, DOI: https://doi.org/10.32861/jssr.spi5.170.174

22. Obadić, A.,Aristovnik, A., (2011),Relativeefficiencyofhighereducationin Croatia andSlovenia: aninternationalcomparison, The AMFITEATRU ECONOMIC journal, AcademyofEconomicStudies - Bucharest, Romania, 13(30), str. 362-376.

23. Odero, E., (2017),Exploringthe Financial PerformanceChallenges at the Municipality of Karibib, European Journal of Research andReflectionin Management Sciences, 5(2), str. 56-73, ISSN 2056-5992

24. OECD, (2015),PublicGovernance\&Territorial Development Directorate. Public Governanceand Territorial Development Directorate. Recommendation of the Council on BudgetaryGovernance. dostupno na:http://www.oecd. org/gov/budgeting/Recommendation-of-the-Council-on-BudgetaryGovernance.pdf,(datum pristupanja: 06.09.2019.)

25. OECD, (2017.a), OECD Recommendationofthe Council on Public Integrity. dostupno na: http://www.oecd.org/gov/ethics/Recommendation-PublicIntegrity. pdf,(datum pristupanja: 06.09.2019.) 
26. OECD, (2017.b),PublicGovernanceDirectorate. Budget Transparency Toolkit. Practicalsteps for supportingopenness, integrityandaccountabilityinPublic Financial Management,Developedbythe OECD withtheparticipationofthe Global Initiative for Fiscal Transparency (GIFT) Network. dostupno na: http://www.oecd.org/gov/budgeting/Budgeting-TransparencyToolkit.pdf,(datum pristupanja: 06.09.2019.)

27. OECD, dostupno na: https://www.oecd.org/gov/budgeting/principlesbudgetary-governance.htm(datum pristupanja: 06.09.2019.)

28. Ozkul, F., Alkan, B. S., (2017), Financial conditionanalysisinMunicipalities: a caseofTurkey, MarmaraÜniversitesiÖneriDergisi, 12(48), str.153-174, DO1: 10.14783/maruoneri.vi.331667

29. Phatudi, S., (2010), An analysisofthefinancialviabilityofmunicipalitiesinthe North West Province: ThecasestudyofMafikengLocalMunicipality, Mini Dissertationsubmittedinpartialfulfillment for thedegreeofMastersin Business Administration (MBA) at the North West University GraduateSchool

30. Pravilnik o proračunskom računovodstvu i računskom planu, Narodne novine broj Narodne novine br. 124/2014, 115/2015, 87/2016, 3/2018, dostupno na: https://narodne-novine.nn.hr/clanci/sluzbeni/2014_10_124_2374.html (datum pristupanja: 31.08.2019.)

31. Ramli, Z., Masud, J., Haron, S. A., Othman, M., Awang, A. H., Md Sum, S., (2013), Financial well-being: Financial ratioanalysis of married public sector workers in Malaysia. Asian Social Science, 9(14), str. 1-6. https://doi.org/10.5539/ass.v9n14p1

32. Ramsey, T. K., (2013), MeasuringandEvaluatingthe Financial Condition of Local Government. A Thesis,TheFacultyofthe Department of Public Policy and Administration California State University, Sacramento, Master of Public PolicyandAdministration.

33. Roje, G., (2008.), Elementi i pokazatelji financijskog položaja države - osvrt na međunarodna iskustva. Riznica, Zagreb: Hrvatska zajednica računovođa i financijskih djelatnika, 2008(2), str. 28-31.

34. Sever, I., Drezgić, S.,Blažić, H., (2011), Budget spending and economic growth in Croatia - Dynamics and relathionships over the past two decades, ZbornikradovaEkonomskogfakulteta u Rijeci: časopis za ekonomskuteorijuipraksu, 29(2), str. 291-331.

35. Sever, S., Žager, L., (2008.), Analiza financijskih izvještaja kao instrument kontrole u javnom sektoru. Hrvatski javni sektor-praksa i perspektive, ZagrebOpatija (ur. Vašiček, D.), Zagreb: HZRFD, str. 434-443.

36. Suarez, V., Lesneski, C.,Denison, D., (2011.),MakingtheCase for Using Financial IndicatorsinLocalPublic Health Agencies. Am J Public Health, 101(3), str. 419-425. 
37. Šegota, A., Cerović, Lj., Maradin, D., (2017), Efficiency of municipal service providers in the Republic of Croatia, Croatian Operational Research Review, CRORR 8(2017), str. 537-562.

38. The Canadian Institute of Chartered Accountants (CICA), (1997), Indicators of Government Financial Condition, dostupno na: https://www.gnb.ca/oagbvg/2001/chap2e.pdf (datum pristupanja: 31.08.2019.)

39. The International City/County Management Association's (ICMA), (2003), Evaluating Financial Condition: A Handbook for LocalGovernment, 4th edition, Intl City County Management Assn (ISBN-13: 978-0873261357)

40. ThePublicSectorAccountingBoard (PSAB), (2010), Statements of Recommended Practice (SORP) 4: Indicatorsof Financial Condition, available at: https://oag-ns.ca/sites/default/files/publications/2010\%20-\%20Nov\%20$\% 20 \mathrm{Ch} \% 2006 \% 20 \% 20$ Indicators $\% 20$ of $\% 20$ Financial $\% 20$ Condition.pdf,(datu m pristupanja: 31.08.2019.)

41. Upreti, P., (2015),FactorsAffectingEconomicGrowthinDevelopingCountries, Major ThemesinEconomics, 17, str. 37-54., dostupno na: https:// scholar works.uni.edu/mtie/vol17/iss1/5 (datum pristupanja: 13.09.2019.)

42. Uredba o indeksu razvijenosti, Narodne novine broj 131/2017

43. Vitezić, N., Šegota, A.,Setnikar-Cankar, S., (2016), Measuring the Efficiency of Public Health Servicesby DEA, International PublicAdministrationReview, 14(4), str. 27-48.

44. Vlah Jerić, S., Primorac, M., (2017), Data mining for assessing the creditrisk of local governmentunitsin Croatia, Croatian Operational Research Review, CRORR 8(2017), str. 193-205.

45. Zakon o proračunu, Narodne novine broj 87/2008, 136/2012, 15/2015. dostupno na: https://narodne-novine.nn.hr/clanci/sluzbeni/2008_07_87_2791. html (datum pristupanja: 31.08.2019.) 


\title{
Ana Ježovita, PhD
}

Faculty of Economics \& Business, University of Zagreb, Zagreb, Croatia

ajezovita@efzg.hr

\section{DIFFERENCES IN EFFECTIVENESS AND FINANCIAL CONDITION OF BUDGET USERS IN CROATIA}

Received: July 15, 2019

Accepted: November 16, 2019

\section{Preliminary communication}

\begin{abstract}
Central, regional and local government units, through their harmonized actions, should strive for efficiency and effectiveness in their activities, which will result in adding value to national wealth and increasing the average standard of living. Unlike profit-oriented systems, the primary goal of budget users is earmarked, efficient and effective distribution of revenues. Activities of budget users should be aimed at effectiveness, sustainability, and continuity of the system. The OECD has an important role in accomplishing the objectives of public sector units by its principles of budgetary governance. Pillars of modern budgetary governance are principles of the transparent and accountable approach to planning and achievement of objectives, and integrity. Accordingly, the research problem includes the question of how the performance and financial condition of budget users can contribute to national wealth. The research objective is to analyse and evaluate the performance and financial condition of budget users in Croatia at local, regional and central government level for the years 2011 to 2017. The result may contribute to detecting problem areas of budget users' governance politics and finding ways of solving them. Additionally, the results may help as a starting point for more detailed research on specific areas in which budget users are able, by its politics and earmarked distribution of revenues, to have a greater impact on welfare in Croatia. The analysis includes 80 budget users for the seven-year period. The data were obtained by e-mail from Annual Financial Reports Registry managed by Financial Agency, and it was processed by using descriptive statistics, correlation analysis, a non-parametric test (Kruskal-Wallis test) and data envelopment analysis. The results of the research indicate that there are statistically significant differences in the performance and financial condition of budget users at the local, regional and central government level. Additionally, the results show that financial ratios give a more detailed evaluation of performance and financial condition compared to a single efficiency indicator which is the
\end{abstract}


result of data envelopment analysis. The results indicate that larger budget users have better performance and financial condition compared to smaller units. Finally, the research results show that there is no positive correlation between the level of efficiency and development index of the geographical area of activity of the budget user.

Keywords: budget users, effectiveness and efficiency, financial condition, financial indicators, data envelopment analysis, development index

JEL: H21, H7, M41, M48 